GARY GORTON

Yale University

ANDREW METRICK

Yale University

\title{
Regulating the Shadow Banking System
}

ABSTRACT The shadow banking system played a major role in the recent financial crisis but remains largely unregulated. We propose principles for its regulation and describe a specific proposal to implement those principles. We document how the rise of shadow banking was helped by regulatory and legal changes that gave advantages to three main institutions: money-market mutual funds (MMMFs) to capture retail deposits from traditional banks, securitization to move assets of traditional banks off their balance sheets, and repurchase agreements (repos) that facilitated the use of securitized bonds as money. The evolution of a bankruptcy safe harbor for repos was crucial to the growth and efficiency of shadow banking; regulators can use access to this safe harbor as the lever to enforce new rules. History has demonstrated two successful methods for regulating privately created money: strict guidelines on collateral, and government-guaranteed insurance. We propose the use of insurance for MMMFs, combined with strict guidelines on collateral for both securitization and repos, with regulatory control established by chartering new forms of narrow banks for MMMFs and securitization, and using the bankruptcy safe harbor to incentivize compliance on repos.

\footnotetext{
A fter the Great Depression, by some combination of luck and genius, the United States created a bank regulatory system that oversaw a period of about 75 years free of financial panics, considerably longer than any such period since the founding of the republic. When this quiet period finally ended in 2007, the ensuing panic did not begin in the traditional system of banks and depositors, but instead was centered in a new "shadow" banking system. This system performs the same functions as traditional banking, but the names of the players are different, and the regulatory structure is light or nonexistent. In its broadest definition, shadow banking includes such familiar institutions as investment banks, money-market
} 
mutual funds (MMMFs), and mortgage brokers; some rather old contractual forms, such as sale-and-repurchase agreements (repos); and more esoteric instruments such as asset-backed securities (ABSs), collateralized debt obligations (CDOs), and asset-backed commercial paper (ABCP). ${ }^{1}$

Following the panic of 2007-09, Congress passed major regulatory reform of the financial sector in the Dodd-Frank Wall Street Reform and Consumer Protection Act of 2010. Dodd-Frank includes many provisions relevant to shadow banking; for example, hedge funds must now register with the Securities and Exchange Commission (SEC), much over-thecounter derivatives trading will be moved to exchanges and clearinghouses, and all systemically important institutions will be regulated by the Federal Reserve. Retail lenders will now be subject to consistent, federal-level regulation through the new Consumer Financial Protection Bureau housed within the Federal Reserve.

Although Dodd-Frank takes some useful steps in the regulation of shadow banking, there are still large gaps where it is almost silent. Three important gaps involve the regulation of MMMFs, securitization, and repos. Fortunately, the law also created a council of regulators, the Financial Stability Oversight Council, with significant power to identify and manage systemic risks, including the power to recommend significant changes in regulation, if deemed necessary for financial stability. ${ }^{2} \mathrm{We}$ will argue that the above three areas played the central role in the recent crisis and are in need of further regulation.

MMMFs, securitization, and repos are key elements of what has been called off-balance-sheet financing, which differs from the on-balance-sheet financing of traditional banks in several important ways. Figure 1 is the classic textbook depiction of the financial intermediation of loans on bank balance sheets in the traditional banking system. In step A depositors transfer money to the bank in return for credit on a checking or savings account, from which they can withdraw at any time. In step B the bank lends these funds to a borrower and holds this loan on its balance sheet to maturity.

1. Some of the important shadow banking terms are defined later in the paper and in the appendix. In other work (Gorton and Metrick 2010, forthcoming), we refer to the specific combination of repos and securitization as "securitized banking." Since this paper takes a broader view to include activities beyond repos and securitization, we use the more common but less precise term "shadow banking."

2. This power, crucial for the future regulation of shadow banking, is granted in section 120 of the Dodd-Frank legislation. Although any new regulations cannot exceed current statutory authority, this authority would still allow for significant new regulation of MMMFs, repos, and securitization without the need for new legislation. 
Figure 1. Traditional On-Balance-Sheet Intermediation

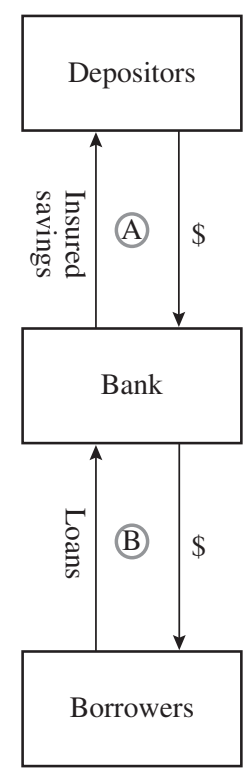

Historically, the traditional system was subject to bank runs, but these were ended in the United States in 1934 through the introduction of federal deposit insurance. With deposits thus insured, depositors have little incentive to withdraw their funds when the solvency of the bank comes into question. Deposit insurance works well for retail investors but leaves a challenge for institutions with large cash holdings. With deposit insurance capped at \$100,000 per account, institutions such as pension funds, mutual funds, states and municipalities, and cash-rich nonfinancial companies lack easy access to safe, interest-earning, short-term investments. The shadow banking system of off-balance-sheet lending (figure 2) provides a solution to this problem.

Step 2 in figure 2 is the analogue to step A in figure 1, but with one important difference. To achieve protection similar to that provided by deposit insurance, an MMMF or other institutional investor receives collateral from the bank. In practice, this transaction takes the form of a repo: the institutional investor deposits $\$ \mathrm{X}$ and receives some asset from the bank as collateral; the bank agrees to repurchase the same asset at some future time (perhaps the next day) for $\$ \mathrm{Y}$. The percentage $(\mathrm{Y}-\mathrm{X}) / \mathrm{X}$ is called the repo rate and (when annualized) is analogous to the interest rate on a bank deposit. 
Figure 2. Off-Balance-Sheet Intermediation in the Shadow Banking System

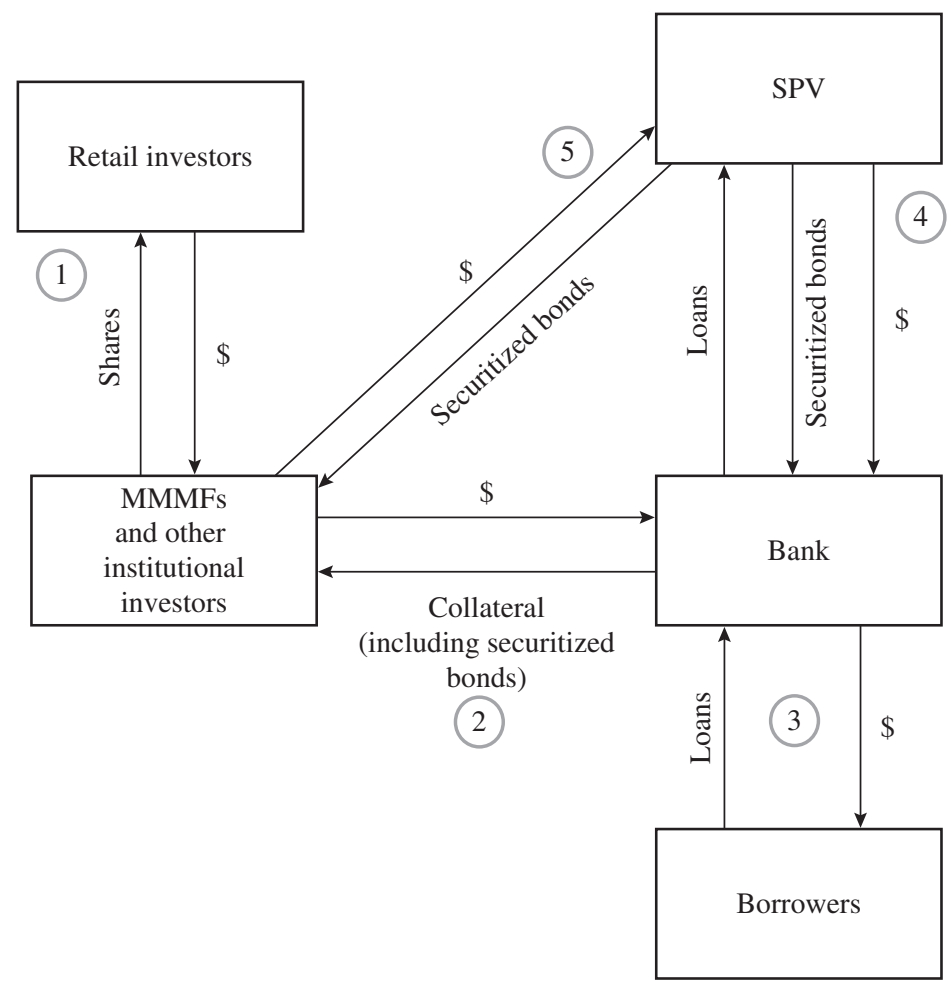

Typically, the total amount deposited will be some amount less than the value of the asset used as collateral; the difference is called a "haircut." For example, if an asset has a market value of $\$ 100$ and a bank sells it for $\$ 80$ with an agreement to repurchase it for $\$ 88$, the repo rate is 10 percent $(=[88-80] / 80)$ and the haircut is 20 percent $([100-80] / 100)$. If the bank defaults on its promise to repurchase the asset, the investor keeps the collateral. $^{3}$

The step that moves this financing off the balance sheet of the bank is step 4, where loans are pooled and securitized. We will discuss this step in

3. As we discuss later, repos are carved out of the Chapter 11 bankruptcy process: They are not subject to the automatic stay rule. If one party to the repo transaction fails, the other party can unilaterally terminate the transaction and keep the cash or sell the bond, depending on which side of the transaction that party has taken. 
Figure 3. Money Market Mutual Funds, Mutual Funds, Demand Deposits, and Bank Assets, 1975-2008

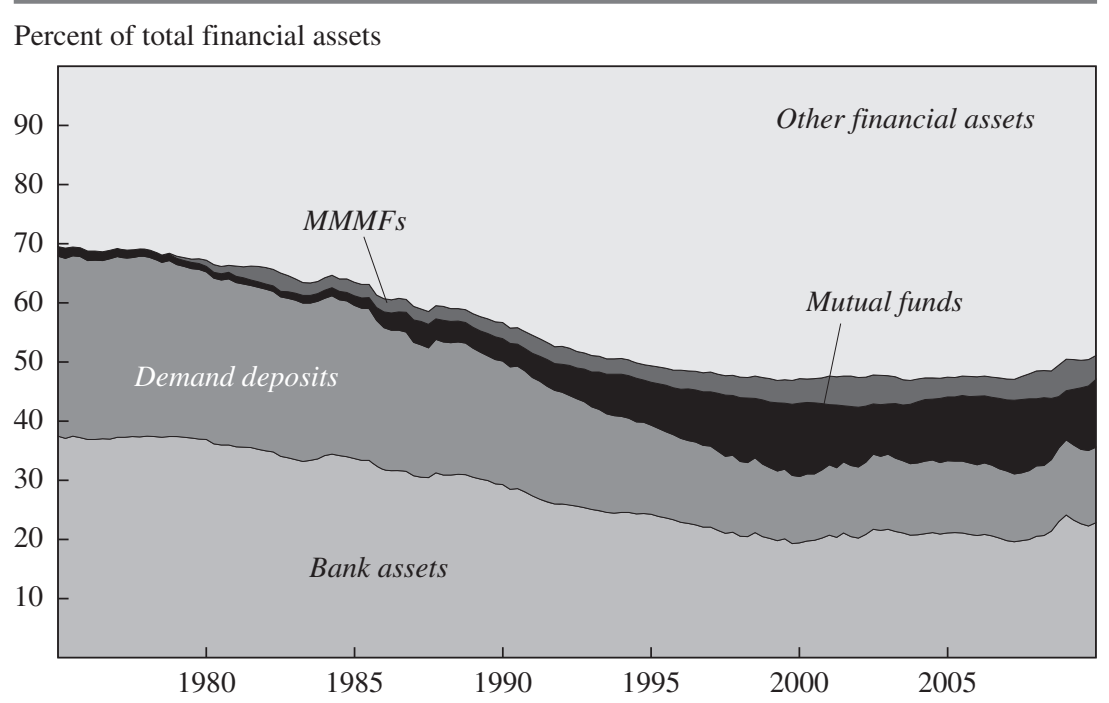

Source: Federal Reserve Flow of Funds data.

detail in section I. For now, the key idea is that the outputs of this securitization are either purchased directly by institutional investors in step 5 or used as collateral for other loans in step 2. In effect, the bonds created by securitization are often the main source of collateral that provides insurance for large depositors.

Each of the components in this off-balance-sheet financing cycle has grown rapidly since 1980 . The most dramatic growth has been in securitization: Federal Reserve Flow of Funds data show that the ratio of offbalance-sheet to on-balance-sheet loan funding grew from zero in 1980 to over 60 percent in 2007. To illustrate the growth in MMMFs, figure 3 shows total bank assets, bank demand deposits, mutual fund assets, and MMMF assets as percentages of total financial assets: the bank share of total assets fell by about 20 percentage points from 1980 to 2008 .

As we discuss later, there are no comprehensive data measuring the repo market. However, an indication of its growth is the growth in the balance sheets of the institutions that play the role of banks in repo transactions as depicted in figure 2 . Before the crisis, these were essentially the investment banks, or broker-dealers. In order for these institutions to act as banks and offer repos, they needed to hold bonds that could be used as collateral. The 
Figure 4. Assets of Broker-Dealers, Commercial Banks, Households, and Nonfinancial Corporations, 1958-2010

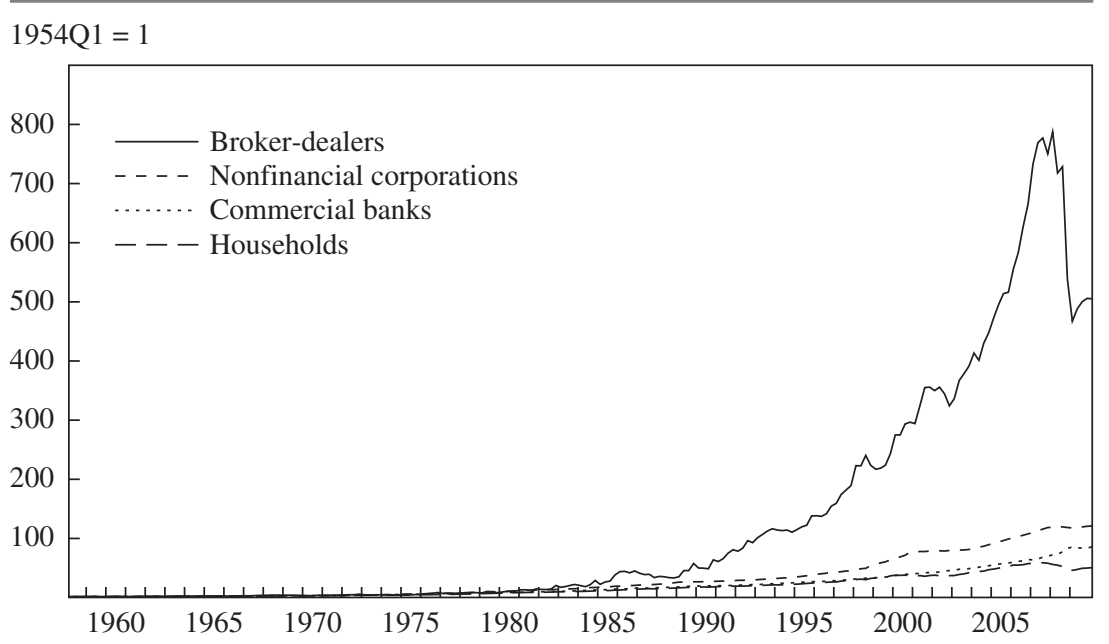

Source: Federal Reserve Flow of Funds data.

yield on the collateral accrues to the bank, which pays the repo rate. So, for example, if the bond is an asset-backed security with a coupon rate of 6 percent, and the repo rate is 3 percent, the bank earns the difference. This required that their balance sheets grow significantly as the repo market grew. Figure 4 shows that broker-dealer assets indeed grew rapidly after about 1990, while commercial bank assets grew at a rate much closer to that of GDP.

Why did shadow banking grow so much? We address this question in section I. One force came from the supply side, where a series of innovations and regulatory changes eroded the competitive advantage of banks and bank deposits. A second force came from the demand side, where demand for collateral for financial transactions gave impetus to the development of securitization and the use of repos as a money-like instrument. Both of these forces were aided by court decisions and regulatory rules that allowed securitization and repos special treatment under the bankruptcy code. A central idea of this paper is that the bankruptcy safe harbor for repos has been crucial to the growth of shadow banking, and that regulators can use access to this safe harbor as the lever to enforce minimum repo haircuts and control leverage. 
If the growth of shadow banking was central to the crisis and was facilitated by regulatory changes, then why not simply reverse all these changes? Would such reversals bring us back to a safer system dominated by traditional banks? We do not believe that such a radical course is possible even if it were desirable, which it is not, in our view. The regulatory changes were, in many cases, an endogenous response to the demand for efficient, bankruptcy-free collateral in large financial transactions: if repos had not been granted this status, the private sector would have sought a substitute, which likely would have been even less efficient. In any case, we will not try in this paper to justify the existence of the shadow banking system. Instead we take the broad outlines of the system as given and ask how the current regulatory structure could be adapted to make the system safer without driving its activity into a new unregulated darkness.

In section II we discuss how the shadow banking system broke down in the crisis. The features of this breakdown are similar to those from previous banking panics: safe, liquid assets suddenly appeared to be unsafe, leading to runs. MMMFs, which appeared to be as safe as insured deposits to many investors, suddenly appeared vulnerable, leading to runs on those funds. Securitization, which investors had trusted for decades as creating a form of "information-insensitive" securities free of adverse selection problems, suddenly lost the confidence of investors: hundreds of billions of dollars of formerly information-insensitive triple-A-rated securities became information-sensitive. ${ }^{4}$ Since the cost of evaluating all this newly suspect paper was high, investors simply exited all securitizations. In this new environment the high-quality collateral necessary for repos no longer existed. In Gorton and Metrick (forthcoming), we claim that the resulting run on repos was a key propagation mechanism in the crisis.

Section III applies lessons from the successful regulation of traditional banking to infer principles for the regulation of shadow banking. History has demonstrated two methods for reducing the probability of runs in a system. The first, standardized collateralization, was introduced after the Panic of 1837, when some states passed free banking laws under which state bonds were required to back paper bank notes. Free banking laws were the basis for the National Bank Acts, which created national bank notes backed by

4. The "information-sensitive" and "information-insensitive" nomenclature comes from Dang, Gorton, and Holmström (2010a, 2010b). "Information-insensitive" roughly means that the cost of producing private information about the payoff on the security is not worth bearing by potentially informed traders. Such securities do not face adverse selection when sold or traded. But a crisis occurs when a shock causes production of such private information to become profitable. 
U.S. Treasury securities as collateral; these notes were the first currency in the United States to trade at par against specie. The second method, government insurance, was tried at the state level without great success before the Civil War and again in the first decades of the 20th century. Success finally came when, during the Great Depression, the Federal Deposit Insurance Corporation (FDIC) was created to insure demand deposits. This innovation stopped the cycle of runs on demand deposits and allowed them to be used safely as money.

Today, repos have emerged as a new monetary form, and history offers the same two methods to consider for stabilizing their use. As discussed in detail in section IV, which describes our specific proposals, we believe that insurance would be workable for MMMFs, but that collateralization would be preferable for repos and securitization. For MMMFs the problems are straightforward and have already been well addressed by other authors. We adopt the proposal of the Group of Thirty (2009): MMMFs would have the choice of being treated either as narrow savings banks (NSBs) with stable net asset values, or as conservative investment funds with floating net asset values and no guaranteed return. Under this system, the former would fall clearly within the official financial safety net, but the latter would not. ${ }^{5}$

The narrow banks proposed by the Group of Thirty for MMMFs provide a model for regulating securitization based on the chartering of "narrow funding banks" (NFBs) as vehicles to control and monitor securitization, combined with regulatory oversight of acceptable collateral and minimum haircuts for repos. Under this regime the rules for acceptable collateral would allow that collateral to play a role analogous to that of the state bonds backing bank notes in the free banking period, or the U.S. Treasury securities backing greenbacks during the national banking era; minimum repo haircuts would play a role analogous to capital ratios for depository institutions. The danger of exit from this system and the creation of yet another shadow banking system would be mitigated by allowing only licensed NFBs and repos the special protections provided under the bankruptcy code.

Section V concludes with a discussion of related topics in regulation and monetary policy. The appendix supplements the text with a glossary of shadow banking terminology used in the paper.

5. The Group of Thirty (2009) proposal uses the term "special purpose banks" for what we call "narrow savings banks" for terminological consistency with other parts of our proposal. 


\section{The Rise of Shadow Banking}

Shadow banking is the outcome of fundamental changes in the financial system in the last 30 to 40 years, as a result of private innovation and regulatory changes that together led to the decline of the traditional banking model. Faced by competition from nonbanks and their products, such as junk bonds and commercial paper, on the asset side of their balance sheets, and from MMMFs on the liability side, commercial banks became less profitable and sought new profit opportunities. ${ }^{6}$ Slowly, traditional banks exited the regulated sector. In this section we review in more detail the three important changes in banking discussed briefly above: MMMFs, securitization, and repos.

\section{I.A. Money-Market Mutual Funds}

Since the 1970s there has been a major shift in the preferred medium for deposit-like transactions away from demand deposits toward MMMFs. ${ }^{7}$ MMMFs were a response to interest rate ceilings on demand deposits (Regulation Q). In the late 1970s the assets of MMMFs totaled around $\$ 4$ billion. In 1977 interest rates rose sharply and MMMFs grew in response, by more than $\$ 2$ billion per month during the first 5 months of 1979 (Cook and Duffield 1979). The Garn-St. Germain Act of 1982 authorized banks to issue short-term deposit accounts with some transaction features but no interest rate ceiling. These were known as "money-market deposit accounts." Michael Keeley and Gary Zimmerman (1985) document that these accounts attracted $\$ 300$ billion in the 3 months after their introduction in December 1982 , and they argue that the result was a substitution of wholesale for retail deposits, and of direct price competition for nonprice competition, both responses resulting in increased bank deposit costs. MMMFs really took off in the mid-1980s, their assets growing from $\$ 76.4$ billion in 1980 to $\$ 1.8$ trillion by 2000 , an increase of over 2,000 percent. Assets of MMMFs reached a peak of $\$ 3.8$ trillion in 2008 , making them one of the most significant financial product innovations of the last 50 years.

An important feature of MMMFs that distinguishes them from other mutual funds is that they seek to maintain a net asset value of $\$ 1$ per share.

6. These changes have been much noted and much studied, so we only briefly review them here. See Keeley and Zimmerman (1985), Bryan (1988), Barth, Brumbaugh, and Litan (1990, 1992), Boyd and Gertler (1993, 1994), Edwards and Mishkin (1995), and Berger, Kashyap, and Scalise (1995), among many others.

7. MMMFs are registered investment companies that are regulated by the SEC in accordance with Rule 2a-7, adopted pursuant to the Investment Company Act of 1940. 
It is this feature that enables MMMFs to compete with insured demand deposits. MMMFs are closely regulated; they are required, for example, to invest only in high-quality securities that would seem to have little credit risk. The SEC has recently proposed a series of changes to MMMF regulation; these regulations, part of the Investment Company Act of 1940 (as amended), have come under review by a working group of regulators, but none of the recent proposals would change the fact that MMMFs are not explicitly insured. The maintenance of the $\$ 1$ share price was almost universally successful in the decades leading up to the crisis. This may have instilled a false sense of security in investors who took the implicit promise as equivalent to the explicit insurance offered by deposit accounts. The difference, of course, is that banks pay for deposit insurance (and pass that cost along to depositors), whereas the promise to pay $\$ 1$ per share costs the MMMFs nothing. In the crisis, the government made good on the implicit promise by explicitly guaranteeing MMMFs, and in the wake of that move it may not be credible for the government to commit to any other strategy. As long as MMMFs have implicit, cost-free government backing, they will have a cost advantage over insured deposits. We return to this point in section IV, where we adopt the proposals of the Group of Thirty (2009) for MMMFs to either pay for explicit insurance or drop the fiction of stable value.

\section{I.B. Securitization}

Securitization is the process by which traditionally illiquid loans are packaged and sold into the capital markets. This is accomplished by selling large portfolios of loans to special purpose vehicles (SPVs), which are legal entities that in turn issue rated securities linked to the loan portfolios. Figure 5 illustrates how securitization works. An originating firm lends money to a number of borrowers. A number of these loans are then pooled into a portfolio, which is sold to an SPV, a master trust in the figure. The SPV finances these purchases by selling securities in the capital markets. These securities are classified into tranches, which are ranked by seniority and rated accordingly. The whole process thus takes loans that traditionally would have been held on the balance sheet of the originating firm and creates from them marketable securities that can be sold and traded via the off-balance-sheet SPV.

Securitization is a large and important market. Figure 6 shows the annual issuance since 1990 of all securitized products, including nonagency mortgage-backed securities, the major nonmortgage categories (credit card receivables, auto loans, and student loans), and other asset classes; for 
Figure 5. The Securitization Process

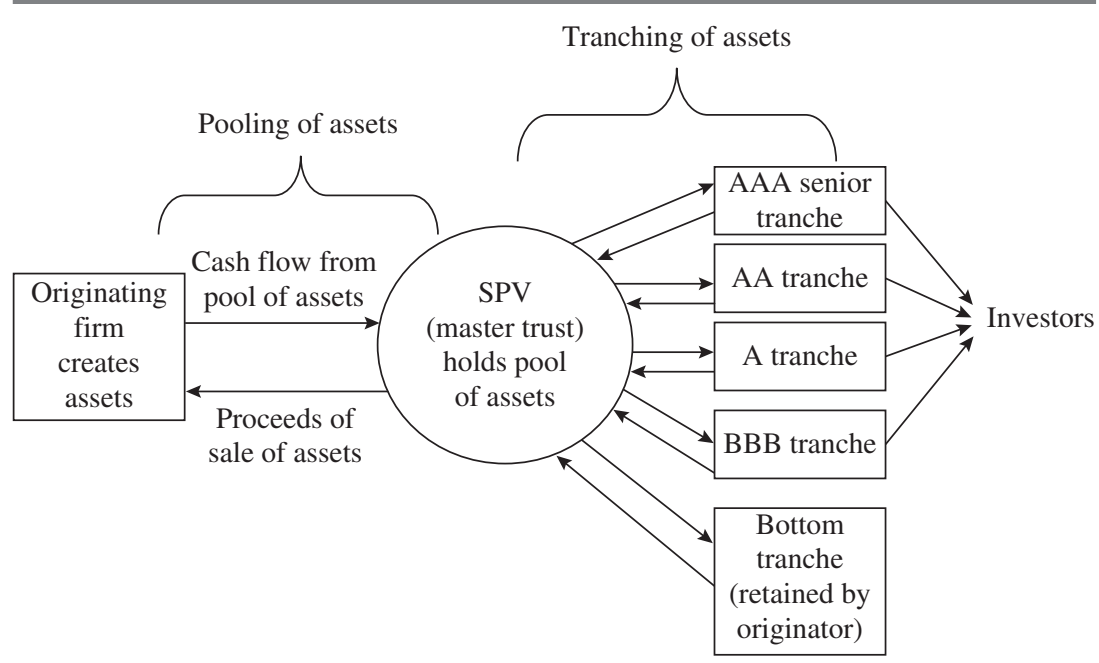

Figure 6. Issuance of Corporate Debt and Asset-Backed Securities, 1990-2009

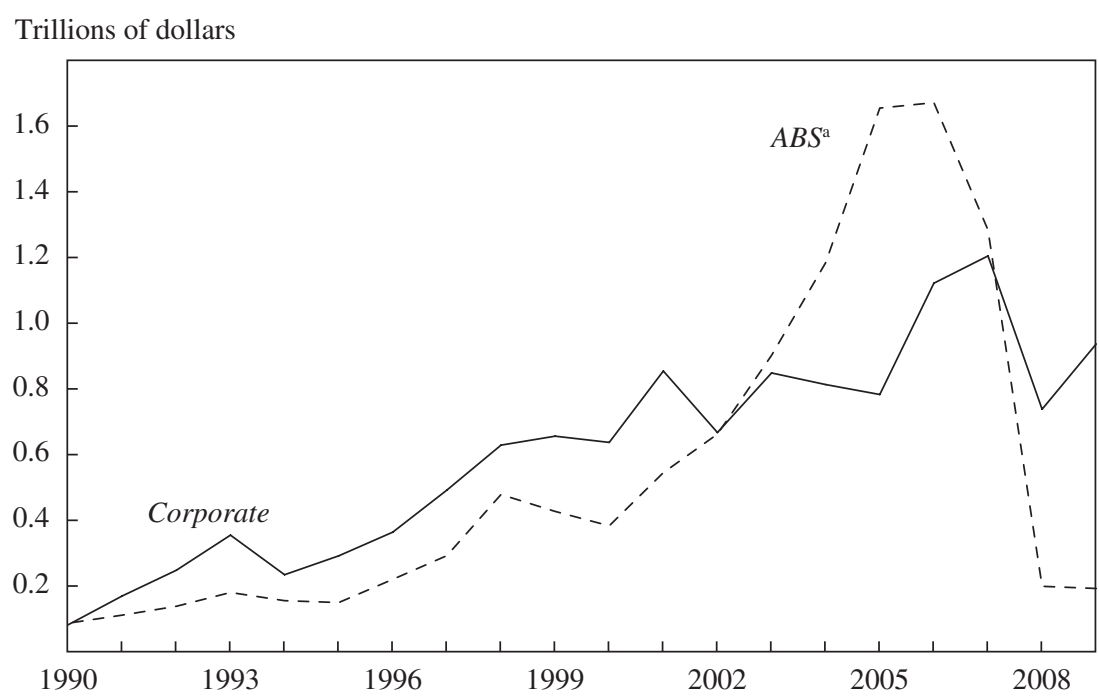

Source: Thomson Reuters.

a. Excludes debt issued by federal government agencies and government-sponsored enterprises. 
comparison, the figure also shows the annual issuance of corporate bonds (including convertible debt). Starting at about the same level, the two series rise roughly in parallel until around 2000, when securitization begins to grow explosively. Securitization peaks in 2006 and then falls precipitously in the crisis.

To understand the potential economic efficiencies of securitization, it is important to understand how the SPV structure works. An SPV has no purpose other than the transaction or transactions for which it was created; it can make no substantive decisions. The rules governing SPVs are set down in advance and carefully circumscribe their activities. Indeed, no one works at an SPV, and it has no physical location. ${ }^{8}$

Two other essential features of an SPV concern bankruptcy. First, SPVs are "bankruptcy remote"; that is, the insolvency of the sponsor (the bank or firm originating the loans) has no impact on the SPV. In particular, creditors of a bankrupt sponsor cannot claw back assets from the SPV. Second, the SPV itself is designed so that it can never, as a practical matter, become legally bankrupt. The most straightforward way to achieve this would be for the SPV to waive its right to file a voluntary bankruptcy petition, but this is legally unenforceable. So the way to minimize the risk of either voluntary or involuntary bankruptcy is to design the SPV in a way that makes the risk of bankruptcy very small. ${ }^{9}$

Why would a bank choose to move some assets off its balance sheet through securitization? There are several costs and benefits of this decision, all of which have been changing rapidly over the last several decades.

BANKRUPTCY. The most important design feature of securitization is that the ABSs issued by an SPV do not trigger an event of default in the case where the underlying portfolio does not generate enough cash to make the contractual coupon payments on the outstanding bonds. ${ }^{10}$ Instead there is an early amortization event: the cash that is available is used to make principal payments early, rather than coupon payments.

8. This description of securitization and SPVs is based on Gorton and Souleles (2006).

9. See Klee and Butler (2002) for some details on how SPVs are structured to avoid bankruptcy.

10. The LTV Steel case (In re LTV Steel, Inc., No. 00-43866, 2001 Bankr. LEXIS 131 (Bankr. N.D. Ohio Feb. 5, 2001)) threatened the bankruptcy remoteness concept, but the parties settled before a court decision was handed down, and the parties agreed that there had been a "true sale" of the assets to the SPV. Although the outcome was ambiguous, it did not hamper the growth of securitization. There have been no other cases challenging bankruptcy remoteness. See, for example, Kettering (2008), Schwarcz (2002), and Stark (2002). 
Avoiding Chapter 11 bankruptcy is valuable. Thomas Plank (2007, p. 654) compares securitization with what happens to a secured creditor in bankruptcy and concludes that "securitization reduces the bankruptcy tax on secured lenders to originators and owners of mortgage loans and other receivables, and therefore has reduced the bankruptcy premiums charged to the obligors of mortgage loans and other receivables." Gorton and Nicholas Souleles (2006) show empirically that this is an important source of value to securitization.

TAXES. Debt issued off the balance sheet does not have the advantageous tax benefits of on-balance-sheet debt. For profitable firms this can make a large difference. Consider a bank that is deciding how to finance a portfolio of mortgage loans that has the same risk properties as the rest of the bank's assets. Profitable firms with little chance of bankruptcy have a high likelihood of being able to treat the interest on that debt as a deductible expense, and so for these firms it is optimal to finance on the balance sheet. For firms that are less profitable and closer to bankruptcy, which therefore have a lower likelihood of using this tax shield, it will be relatively more advantageous to finance off the balance sheet. Gorton and Souleles (2006) find this to be true empirically, in a study of credit card securitizations. Using credit ratings as a measure of profitability and bankruptcy risk, Moody's (1997a, 1997b) also reaches this conclusion.

MORAL HAZARD. Because the rules governing SPVs permit them very little discretion, once a portfolio of loans has been transferred to an SPV, there is no danger of other activities of the SPV imposing costs on the holders of the securitized bonds. In contrast, the expected bankruptcy costs to the holder of a bank's bonds are affected by the other actions of bank management.

Given the fiduciary responsibilities of corporate directors toward equity holders, and given the familiar principal-agent problems among shareholders, directors, and managers, moral hazard will always be a potential concern for bank bondholders. But this concern can be mitigated by the existence of bank "charter value." As discussed by Alan Marcus (1984), a positive charter value gives a bank an incentive to avoid risk taking that might lead to bankruptcy and the loss of the charter. Bank regulations and positive charter values are complementary in that banks tend to abide by regulations - that is, they internalize risk management—when charter values are high. There is persuasive evidence that, historically, such charter value at banks did improve risk management, but that this value and the protection it provided have decreased over time. The competition from junk bonds and MMMFs, together with deregulation (for example, of interest rate ceilings), 
caused bank charter values to decline, which in turn led banks to increase their risk and reduce their capital. ${ }^{11}$

Given the decline in charter values and the resulting increase in bank risk taking, bank bondholders would face higher moral hazard costs for on-balance-sheet financing and demand higher returns as compensation. This provides a cost advantage to securitization that has been growing over time.

REGULATORY COSTS. One regulatory response to increased risk taking by banks has been the introduction of specific capital requirements. In 1981 regulators announced explicit capital requirements for the first time in U.S. banking history: all banks and bank holding companies were required to hold primary capital of at least 5.5 percent of assets by June 1985 . Virtually all banks did meet these capital requirements by 1986, but it is interesting how this was accomplished: banks that were capital deficient when the new requirements were announced tended to grow more slowly than capital-rich banks (Keeley 1988). ${ }^{12}$

If bank regulators impose capital requirements that are binding (that is, that require banks to hold more capital than they would voluntarily in equilibrium), then, when charter value is low, bank capital will exit the regulated bank industry. One way to do this is through off-balance-sheet securitization, which has no requirements for regulatory capital.

ADVERSE SELECTION. It is sometimes alleged that an investor in securitized bonds faces an adverse selection problem: loan originators who have better information about the loans than the investor has might try to put the worst loans into the portfolio being sold to the SPV. Aware of this problem, investors and sponsoring firms have designed several structural mitigants. First, loan originators are allowed limited discretion in selecting loans for the portfolio to be securitized. The loans are subject to detailed eligibility criteria and specific representations and warranties. Once eligible loans have been specified, either they are selected for the portfolio at random,

11. This process is documented by Keeley (1990), Gorton and Rosen (1995), Demsetz, Saidenberg, and Strahan (1996), Galloway, Lee, and Roden (1997), and Gan (2004), among others.

12. Another important change occurred in 1999, when Congress passed the GrammLeach-Bliley Act. This act permitted affiliations between banks and securities firms; it created a special type of bank holding company, called a financial holding company, which is allowed to engage in a wider range of activities (such as insurance underwriting and merchant banking) or under less stringent regulations (for example, on securities underwriting and dealing) than traditional bank holding companies. Before then, the ability of banks to engage in such activities had been strictly constrained by the 1933 Glass-Steagall Act and the Bank Holding Company Act of 1956. 
or all the qualifying loans are put into the portfolio. Second, originators of securitizations retain a residual interest (essentially the equity position) in them. In principle, these features align the interests of securitization investors and loan originators (Gorton 2010), and indeed, except in the case of subprime mortgages, securitization has worked well. When an entire asset class turns out to be suspect, as happened with subprime mortgage securitization, there is clearly a problem, but it is not adverse selection. With respect to subprime securitizations, the evidence on adverse selection remains ambiguous. ${ }^{13}$

TRANSPARENCY AND CUSTOMIZATION. Evaluation of the creditworthiness of any bank requires analyses of its balance sheet, operations, management, competitors, and so on. Information on each of these elements is at best only partly disclosed to bank investors, and even in the absence of moral hazard problems, creditworthiness can vary over time from changes in ordinary business operations. ${ }^{14}$ In comparison, an SPV's portfolio is completely known, and any changes over time are noted in the trustee reports. Although the underlying SPV portfolio may contain thousands of individual assets and is by no means simple to evaluate, it is considerably more transparent than a corresponding bank balance sheet, which may have many such collections of assets and zero disclosure of individual loans.

With the ability to disclose specific assets underlying securitized bonds, off-balance-sheet financing can allow customization of such bonds for any niche of investors. Investors desiring exposure to (or hedges against) mortgages, auto loans, or credit card receivables can purchase exactly what they want through securitized bonds without having to take on exposure to any other type of asset. Furthermore, although banks can and do offer their own debt at different levels of seniority, the transparency of SPV portfolios allows for easier evaluation of the different tranches. One specific type of customization is used to create safe senior tranches that can trade as information-insensitive, triple-A-rated securities. The production of these senior tranches was in part an endogenous response to a rising demand for safe collateral in repos and other financial transactions. We discuss this special case in the next subsection.

13. The recent allegations about the Goldman Sachs Abacus transactions (see the SEC complaint at Securities and Exchange Commission v. Goldman Sachs \& Co. and Fabrice Tourre, www.sec.gov/litigation/complaints/2010/comp21489.pdf) concern synthetic CDOs, not traditional securitization. Synthetic securitizations were not quantitatively large.

14. Indeed, Morgan (2002) provides evidence that banks are more opaque than nonfinancial firms. 
Figure 7. Financial Assets of Institutional Investors in Five Countries, 1980-2008

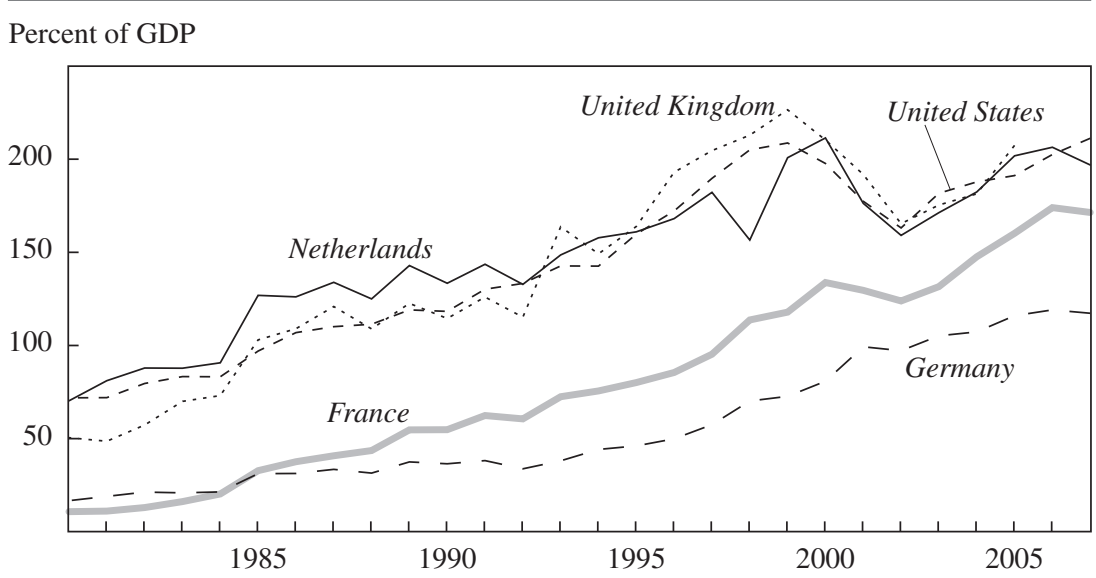

Source: Bank for International Settlements and OECD data.

\section{I.C. Repos}

One key driver of the increased use of repos is the rapid growth of money under management by institutional investors, pension funds, mutual funds, states and municipalities, and nonfinancial firms. These entities hold cash for various reasons but would like to have a safe investment that earns interest, while retaining flexibility to use the cash when needed - in short, a demand deposit-like product. In the last 30 years these entities have grown in size and become an important feature of the financial landscape. For example, according to the Bank for International Settlements (BIS 2007, p. 1, note 1), "In 2003, total world assets of commercial banks amounted to USD 49 trillion, compared to USD 47 trillion of assets under management by institutional investors." Figure 7 shows this increase as a ratio of GDP in five large economies: the median ratio more than tripled from 1980 to 2007.

For large depositors like these, repos can act as a substitute for insured demand deposits because repo agreements are explicitly excluded from Chapter 11: that is, they are not subject to the automatic stay. Instead, repos, like derivatives, have a special status under the U.S. Bankruptcy Code. The repo contract allows either party to unilaterally enforce the termination provisions of the agreement as a result of a bankruptcy filing by the other party. A depositor, for example, can unilaterally terminate its repo with a bank when the bank becomes insolvent and sell the collateral. Without this 
protection, a party to a repo contract would be just another creditor waiting for the bankruptcy proceedings to conclude in order to be repaid. ${ }^{15}$

Repo collateral can be rehypothecated; that is, the collateral received in a repo deposit can be freely reused in another transaction with an unrelated third party. For example, bonds received as collateral can be posted to a third party as collateral in a derivatives transaction; that party can then borrow against the same collateral, and so on. As the BIS (1999, pp. 7-8) has pointed out, this results in "high levels of 'velocity' in repo markets. This occurs when a single piece of collateral is used to effect settlement in a number of contracts on the same day. It allows the daily repo trading volume of a particular note issue to exceed the outstanding amount of the issue, as participants are able to borrow and lend a single piece of collateral repeatedly over the course of a day." Manmohan Singh and James Aitken (2010) argue that measures of repos are significantly larger when rehypothecation is taken into account. ${ }^{16}$

The legal infrastructure facilitating the use of repos as money has evolved as their volume has grown. Since 1978, the year a new bankruptcy code was adopted, both the U.S. Bankruptcy Code and the Federal Deposit Insurance Act have provided exemptions for certain kinds of financial contracts. It was in 1984 that the bankruptcy code was amended to allow parties to a repo to liquidate collateral without the counterparty going into bankruptcy. ${ }^{17}$ But this applied only to repos based on Treasury securities, agency securities, bank certificates of deposit, and bankers' acceptances. ${ }^{18}$ In 2005 the Bankruptcy Reform Act expanded the definition of a repo to

15. See, for example, Johnson (1997) and Schroeder (1996). The safe harbor provision for repo transactions was recently upheld in a court lawsuit brought by American Home Mortgage Investment Corp. against Lehman Brothers. See Schweitzer, Grosshandler, and Gao (2008).

16. Rehypothecation creates a multiplier process for collateral, similar to the more familiar money multiplier. Since there are no official data on repos, the size of this multiplier is not known. Fegatelli (2010) looks at this issue using data from Clearstream, a Luxembourgbased clearinghouse. See also Adrian and Shin (2008), who link the use of repos to monetary policy.

17. The amendment was motivated by the Lombard-Wall decision (see Lombard-Wall, Inc. v. Columbus Bank \& Trust Co., No. 82 B 11556 (Bankr. S.D.N.Y. 1982)), which held that an automatic stay provision prevented the depositor who held the collateral from selling the collateral without court permission. See, for example, Garbade (2006) and Krimminger (2006).

18. It is not clear that actual market practice was limited to this set of securities. In fact, the evidence is that it was not. For example, according to Liu (2003), "In recent years market participants have turned to money market instruments, mortgage and asset-backed securities, corporate bonds and foreign sovereign bonds as collateral for repo agreements." No court cases have tested this. 
make transactions based on any stock, bond, or other security eligible for bankruptcy safe harbor protection. ${ }^{19}$

The unfortunate reality is that no official data on repos exist other than what the Federal Reserve collects with regard to the amounts transacted by the 18 primary dealer banks. According to these data, primary dealers reported financing $\$ 4.5$ trillion in fixed-income securities with repos as of March 4, 2008. However, these data are known to cover only a fraction of the U.S. market. ${ }^{20}$ BIS economists Peter Hördahl and Michael King (2008, p. 37) report that repo markets doubled in size from 2002 to 2007, "with gross amounts outstanding at year-end 2007 of roughly $\$ 10$ trillion in each of the US and euro repo markets, and another $\$ 1$ trillion in the UK repo market." They also report that the U.S. repo market exceeded \$10 trillion in mid-2008, including double counting. ${ }^{21}$ The European repo market, generally viewed as smaller than the U.S. market, was $€ 4.87$ trillion in June 2009, having peaked at $€ 6.78$ trillion in June 2007, according to the International Capital Market Association (ICMA) European Repo Market Survey (2010). According to figures published in ICMA's June 2009 survey, the repo market globally grew at an average annual rate of 25 percent between 2001 and 2007. Although the available evidence strongly suggests that the repo market is very large, it is impossible to say how large it is in the United States.

We have described the repo market as essentially a deposit market, but repos have a number of other significant uses as well. They are used to hedge derivative positions and to hedge primary security issuance. Repos are also important for maintaining "no arbitrage" relationships between cash and synthetic instruments. A very important use of repos is in taking "short" positions in securities markets. By using a repo, a market participant can sell a security that he or she does not own by borrowing it from another party in the repo market. Without a repo market (or an analogous

19. See Krimminger (2006), Garbade (2006), Smith (2007), Sissoko (2010), Johnson (1997), Schroeder (1996), and Walters (1984).

20. Federal Reserve Flow of Funds data cover only the U.S. primary dealers and thus show an even lower figure than the Federal Reserve's other numbers.

21. "Double counting" refers to counting both repo and reverse repo (see the appendix) in the same transaction. The extent of this issue is unclear, as no data exist on the extent of involvement of nonfinancial firms in repos; only financial firms have been counted, estimated, or surveyed. Again, anecdotally, many nonfinancial firms' treasury departments (for example, Westinghouse, IBM, and Microsoft) invest in repos, as do institutional investors and states and municipalities, as discussed above. 
market transaction using collateral), this would be impossible. Repos are also an important mechanism for obtaining leverage, especially for hedge funds. There are many such examples. It is for all these reasons that repos have been described as the core of the financial system (Comotto 2010).

\section{The Role of Shadow Banking in the Financial Crisis}

The chronology of events in the financial crisis of 2007-09 is well known, and a growing number of papers address various aspects of the crisis. ${ }^{22}$ In this section we briefly summarize the crisis as a run on various forms of "safe" short-term debt.

A proximate cause of the crisis was a shock to home prices, which had a large detrimental effect on subprime mortgages. In turn, ABSs linked to subprime mortgages quickly lost value. The shock spread quickly to other asset classes as entities based on short-term debt were unable to roll over the debt or faced withdrawals. Essentially, there was a run on short-term debt. The epicenters were the repo market, the market for ABCP, and MMMFs. We briefly discuss each in turn.

Gorton and Metrick (2010, forthcoming) and Gorton (2010) have argued that the core problem in the financial crisis was a run on repos. The panic occurred when depositors in repo transactions with banks feared that the banks might fail and they would have to sell the collateral in the market to recover their money, possibly at a loss given that so much collateral was being sold at once. In reaction, investors increased repo haircuts. Tri Vi Dang, Gorton, and Bengt Holmström (2010a, 2010b) argue that a haircut amounts to a tranching of the collateral to recreate an information-insensitive security in the face of the shock, so that it is again liquid.

An increase in a repo haircut is tantamount to a withdrawal from the issuing bank. Think of a bond worth $\$ 100$ that was completely financed in the repo market with a zero haircut. A 20 percent haircut on the same bond would require that the bank finance $\$ 20$ some other way. In effect,

22. Among many others, Brunnermeier (2009), Adrian and Shin (2010), Krishnamurthy (2010), He, Khang, and Krishnamurthy (2010), Gorton and Metrick (2010a, 2010b), and Gorton (2010) document and analyze the crisis. Some examples of theory-oriented papers are Acharya, Gale, and Yorulmazer (2009), Brunnermeier and Pedersen (2009), Geanakoplos (2009), Dang, Gorton, and Holmström (2010a, 2010b), He and Xiong (2009), Pagano and Volpin (2009), Shleifer and Vishny (2009), Uhlig (2009), and Martin, Skeie, and von Thadden (2010). 
$\$ 20$ has been withdrawn from the bank. If no one will provide financing to the bank through new security issuance or a loan, the bank will have to sell assets. In the crisis, withdrawals in the form of increased repo haircuts caused deleveraging, spreading the subprime crisis to other asset classes.

It was not only in the repo market that problems occurred. There were also runs on other types of entities that were heavily dependent on short-term debt and held portfolios of ABSs. ABCP conduits and structured investment vehicles (SIVs) are operating companies that purchased long-term ABSs and financed them with short-term debt, largely commercial paper. Just before the crisis began, $\mathrm{ABCP}$ conduits had about $\$ 1.4$ trillion in total assets (Carey, Correa, and Kotter 2009). Most ABCP programs were sponsored by banks. Daniel Covits, Nellie Liang, and Gustavo Suarez (2009, p. 7) report that "more than half of $\mathrm{ABCP}$ daily issuance has maturities of 1 to 4 days [referred to as "overnight"], and the average maturity of outstanding paper is about 30 days" (see also Carey, Correa, and Kotter 2009). Our reform proposals below also address $\mathrm{ABCP}$ conduits and SIVs.

MMMFs were also hit hard during the crisis. MMMFs are not just a retail product; they managed 24 percent of U.S. business short-term assets in 2006 (Brennan and others 2009). At that time, just before the crisis, these funds held liabilities of ABCP conduits, SIVs, and troubled financial firms such as Lehman Brothers. Upon Lehman's failure, concern that these funds would have trouble maintaining their implicit promise of a $\$ 1$ net asset value induced some investors to withdraw their funds. Faced with a run, these entities were forced to sell assets at fire-sale prices (Brennan and others 2009). There was a flight to quality: investors moved assets out of MMMFs that invested mainly in private sector debt and into MMMFs that primarily invested in U.S. Treasury debt. From September to December 2008 , the former suffered a net cash outflow of $\$ 234$ billion while the latter received a net inflow of $\$ 489$ billion (Brennan and others 2009). On September 29, 2008, the government announced its Temporary Guarantee Program for Money Market Funds; this temporarily guaranteed certain account balances in MMMFs that qualified.

In summary, the financial crisis was centered in several types of shortterm debt (repos, $\mathrm{ABCP}, \mathrm{MMMF}$ shares) that were initially perceived as safe and "money-like" but later found to be imperfectly collateralized. In this way the crisis amounted to a banking panic, structurally similar to centuries of previous panics involving money-like instruments such as bank notes and demand deposits, but with the "banks" taking a new form. To regulate this new form of banking, we turn next to the lessons of history. 


\section{Lessons from History and Principles for Reform}

Bank regulation has been at the forefront of public policy issues in finance since the founding of the United States. The essential feature of banking is the provision of "money," that is, a medium that can be easily used to conduct transactions without losses to insiders (that is, the better-informed party). Throughout U.S. history, a central aim of government involvement has been to provide a regulatory structure that ensures the existence of such a safe medium of exchange and avoids systemic banking crises. Before the creation of federal deposit insurance in 1934, the government's efforts to ensure the safety of bank-produced media of exchange took two primary forms. The first was safe and transparent collateral backing for bank money. The idea was that instead of backing bank money with opaque long-term loans, it should be backed by specified government securities. The second was various kinds of insurance schemes tried by the states. It is also worth commenting briefly on the role of private bank clearinghouses, which developed into institutions that sought to safeguard the credibility of bank money. In this section we briefly review these regulatory attempts.

Before the Civil War the predominant form of bank money was privately issued bank notes. These were issued by banks at par, but when used at some distance from the issuing bank, they were accepted only at a discount (see, for example, Gorton 1996, 1999). This early period of banking in the United States was plagued with difficulties, and various solutions were proposed. For the sake of brevity, we start our examination with the Panic of 1837.23

The Panic of 1837 disclosed the defects of the New York Safety Fund System and ushered in that state's Free Banking Act of 1838. ${ }^{24}$ The Safety Fund had been established in New York in 1829 as an insurance system. Each member bank was required to make periodic contributions, as a percentage of its capital, to a fund for the payment of the debts of any insolvent member after its own assets had been exhausted. Of course, the problem was that the bank had to be insolvent in order for claims to be made on the fund, but at least in principle the note holders would not suffer losses. The Panic of 1837 was the first test of the Safety Fund. Banks suspended convertibility of notes and deposits into specie in May of that year. Later that year came the first calls on the Safety Fund. In the end, the fund was

23. For a history of U.S. banking before this period, see, among others, Knox (1900).

24. We focus here on New York, which was the most important state in this history in many ways. For more general treatments, see, for example, Dewey (1910), Golembe (1960), and Rockoff (1974). 
not adequate to meet all the demands made on it from the debt of insolvent banks, even with an extra tax on member banks. The fund was basically abandoned: although it continued for chartered banks until 1866, very few banks participated.

New York's Free Banking Act, imitated by many (but not all) other states, introduced a fundamental idea into the design of banking: the use of explicit and mostly transparent collateral to back the issuance of private money. ${ }^{25}$ Free banking laws had the following standard features: entry was relatively easy, requiring no special state legislation (previously a state banking charter had required a specific act of the legislature); free banks were required to post eligible state bonds with the state auditor as collateral for notes issued (some states allowed federal bonds also); free banks were required to pay specie on demand or would (after a grace period) forfeit their charter; free banks were organized as limited liability firms. Our concern is with the bond collateral. The eligible bonds were publicly known, and what bonds were posted by each bank was also known. The state auditor kept the bank's printing plates and printed the notes.

The bond backing system worked in principle, but in practice the collateral - the state bonds-was not riskless. Arthur Rolnick and Warren Weber (1984) show that free banks failed when the value of the bonds they posted as collateral fell. The Panic of 1857, which largely involved another bank liability that had grown enormously, namely, demand deposits, revealed the deficiencies of a system that backed note issuance with bank bonds.

The use of bond collateral for note issuance under the free banking laws was the basis for the most successful financial legislation in U.S. history, the National Bank Acts. According to Andrew Davis (1910, p. 7), "The success of [free banking] suggested that a uniform national currency might in the same way be provided through the emissions of special associations [national banks], which should secure their notes by the pledge of government securities." Partly as a way of financing the Civil War, Congress passed the National Bank Acts in 1863 and 1864 to create a uniform federal currency. National bank notes were liabilities of a new category of banks, called "national banks." They could issue notes upon depositing U.S. Treasury securities with the federal government equal in face value to 111 percent (later reduced to 100 percent) of the value of notes issued. After the Panic of 1873, banks were further required to make deposits into

25. Connecticut, Florida, Illinois, Indiana, Iowa, Louisiana, Massachusetts, New Jersey, Ohio, Pennsylvania, Tennessee, Vermont, Virginia, and Wisconsin adopted free banking laws before the Civil War. 
a Treasury-run redemption fund. As Milton Friedman and Anna Schwartz (1963, p. 21) summarized, "Though national bank notes were nominally liabilities of the banks that issued them, in effect they were indirect liabilities of the federal government thanks to both the required government bond security and the conditions for their redemption." National bank notes circulated at par, and there were none of the problems that had plagued the antebellum period. But although these notes remained safe, panics did occur during the national banking period, in 1873, 1884, 1893, 1907, and 1914. It was these panics, centered on demand deposits rather than bank notes, that eventually led to the creation of federal deposit insurance through the FDIC.

Deposit insurance has a long history in the United States, dating back to the New York Safety Fund System briefly discussed above. Before the FDIC was created, there were numerous state-organized insurance schemes. Before the Civil War, in addition to New York, Indiana, Iowa, Michigan, Ohio, and Vermont organized such systems. These had different designs, and whereas some can be described as successful (Indiana, Iowa, and Ohio), others were not. Although deposits were not insured under the national banking system, the National Bank Acts were followed by a halt to state insurance programs for almost 50 years. After the Panic of 1907, however, some states again introduced deposit insurance programs, notably Oklahoma, which was then followed by a number of other states, including Kansas, Mississippi, Nebraska, North Dakota, South Dakota, Texas, and Washington. All collapsed during the 1920s, when agricultural prices fell (see Golembe 1960, Calomiris 1989, 1990).

During the national banking era, private bank clearinghouses in various cities undertook the role of monitoring banks, and in the Panics of 1893 and 1907 they provided a kind of insurance. When suspension of convertibility occurred, organized by the clearinghouse, the clearinghouses would not exchange currency for checks. But they did issue clearinghouse loan certificates, in small denominations that could be used as money, in both 1893 and 1907. These certificates were the joint liability of all members of that clearinghouse that were located in its city. Thus, claims on an individual bank that might be insolvent were replaced with claims on the group of banks (see Gorton and Mullineaux 1987, Gorton 1985).

To summarize, after the Civil War, collateral backing by specified eligible bonds under the National Bank Acts solved the problems with bank notes but left demand deposits vulnerable to panic. The problem of demand deposit panics was solved only in 1934 with the creation of federal deposit insurance. 


\section{Some Proposals for the Regulation of Shadow Banking}

Our proposals are based on two themes developed in the paper:

-An important cause of the recent panic was that seemingly safe instruments like MMMF shares and triple-A-rated securitized bonds suddenly seemed unsafe. New regulation should seek to make it clear, through either insurance or collateral, which instruments are truly safe and which are not.

- The rise of shadow banking was facilitated by a demand-driven expansion in the bankruptcy safe harbor for repos. This safe harbor has real value to market participants and can be used to bring repos under the regulatory umbrella.

We use these themes to develop our specific proposals for MMMFs, securitization, and repos.

\section{IV.A. MMMFs: Narrow Savings Banks or Floating Net Asset Values}

The central regulatory problem for MMMFs is simple: MMMFs compete in the same space as depository banks, but differ from them in providing an implicit promise to investors that they will never lose money. This promise, for which the MMMFs do not have to pay, was made explicit by the government in the recent crisis. This problem is well understood and has been discussed for many years by academics and regulators. To solve it, we adopt the specific proposal of the Group of Thirty (2009), which is concise enough that we quote it in full:

a. Money market mutual funds wishing to continue to offer bank-like services, such as transaction account services, withdrawals on demand at par, and assurances of maintaining a stable net asset value (NAV) at par should be required to reorganize as special-purpose banks, with appropriate prudential regulation and supervision, government insurance, and access to central bank lender-of-last-resort facilities.

b. Those institutions remaining as money market mutual funds should only offer a conservative investment option with modest upside potential at relatively low risk. The vehicles should be clearly differentiated from federally insured instruments offered by banks, such as money market deposit funds, with no explicit or implicit assurances to investors that funds can be withdrawn on demand at a stable NAV. Money market mutual funds should not be permitted to use amortized cost pricing, with the implication that they carry a fluctuating NAV rather than one that is pegged at US\$1.00 per share.

The logic of this proposal-the elimination of "free" insurance for MMMFs-seems powerful. So why has it not been adopted? One reason is that the MMMF industry is reluctant to part with free insurance, and a $\$ 4$ trillion industry can make for a powerful lobby. A second reason is that 2010 still seems a dangerous time to be disrupting such a large short-term 
credit market. We certainly are sympathetic to this second reason, but we believe that any changes can be decided now and implemented after the credit markets have recovered.

Our only tweak on the Group of Thirty proposal is that we call their special-purpose banks "narrow savings banks," or NSBs. We do this to underline the analogy to our "narrow funding banks" (NFBs) for securitization, as described in the next subsection.

\section{IV.B. Securitization: Narrow Funding Banks}

The basic idea of NFBs is to bring securitization under the regulatory umbrella. What may seem radical at first glance becomes less so when it is recognized that securitization is just banking by another name, and that it makes sense to regulate similar functions with similar rules. Indeed, the logic is the same as that for the creation of NSBs in place of MMMFs. NFBs would be genuine banks with charters, capital requirements, periodic examinations, and access to the Federal Reserve's discount window. Under the proposal, all securitized products must be sold to NFBs; no other entity would be allowed to buy ABSs. (NFBs could also buy other high-grade assets, such as U.S. Treasury securities.) NFBs would be new entities located between securitizations and final investors. Instead of buying ABSs, final investors would buy the liabilities of NFBs.

An NFB regulator would design and monitor the criteria for NFB portfolios. It would determine what classes of ABSs are eligible for purchase by NFBs and would determine the criteria governing the allowed proportions of different asset classes in the portfolio and the proportions of assets of different ratings. With these rules, the regulator would be setting collateral requirements for NFBs in the same way that the National Bank Acts set collateral requirements for bank notes in the 19th century, and in the same way that bank regulators set capital requirements in the 21 st century.

Note that under the Group of Thirty's proposal, the government would offer explicit government insurance for what we are calling NSBs, just as it does today for depository banks. Such insurance would be workable for NSBs because all holdings of these banks would have the same seniority, and the entire portfolio would be required to have low risk. Securitization is different. Because ABSs typically have multiple tranches, we do not believe that insurance would be a practical solution: the subordinated components would have some risk and could not be insured, and insurance on the senior components would exacerbate the information problems in the subordinated components. It would defeat the purpose of our proposed regulatory structure 
to create a new form of government guarantee only to create a new form of adverse selection. Thus, we have proposed collateralization combined with supervision, but we acknowledge that this combination cannot provide the same 100 percent protection as government insurance. For that reason NFB liabilities can never be considered perfect substitutes for government debt, and the Federal Reserve would need to ensure a sufficient supply of non-NFB collateral. We return to this important point in section V.

Our proposal does place new burdens on the regulatory system. The NFB regulator would have to monitor NFB portfolios and perhaps take corrective action. Would it be up to the task? We believe that this task is no different from that faced by traditional bank regulators. The NFB regulator would need to assess the risks of each NFB's activities and evaluate the amount of capital it needed. If the regulatory system is incapable of performing this activity for NFBs, it will be equally challenged if these activities remain on the balance sheets of traditional banks.

NFBs would be a different category of bank because their activities would be so narrowly circumscribed; they would be rules-driven, transparent, stand-alone, newly capitalized entities that could buy only ABSs and other low-risk securities and issue liabilities. They would not be allowed to take deposits, make loans, engage in proprietary trading, or trade derivatives. These limitations would result in a much lower risk profile than traditional banks have, with lower earnings volatility and a much lower return on equity. ${ }^{26}$

NFBs can be viewed as regulated collateral creators or repo banks. They would be allowed to fund themselves through repos. They could engage in repo transactions with private depositors, as could other entities as discussed below. Since all ABSs would have to be sold to NFBs, NFBs would subsume the function of ABCP conduits, SIVs, and related limited-finance companies. These other entities could become NFBs but would have to sever ties with bank sponsors and meet the other NFB requirements. NFBs would therefore complement traditional banks' origination and securitization activities. As in the precrisis economy, traditional banks could fund

26. For greater concreteness we provide an abbreviated sample term sheet indicating the main features of a NFB at the Brookings Papers website. As the sample term sheet indicates, if capital or other triggers are hit, the NFB would automatically go into a limited, "no growth mode," and if it does not recover, it would automatically go into wind-down, in a process we call "natural amortization." This would be a form of living will governing all the points of transition between operating states. There would be no bailouts of NFBs. 
loans through securitization, but the resulting ABSs would have to be purchased by NFBs.

\section{IV.C. Repos: Licenses, Eligible Collateral, and Minimum Haircuts}

There are two sides to a repo contract: the depositor, who provides cash to the bank in exchange for interest and receives collateral (the transaction is a "reverse repo" from the depositor's perspective), and the bank, which receives the money and initially holds the bonds used as collateral. In the crisis the problem was that the housing price shock caused securitized products to become information-sensitive, leading to withdrawals from the repo market, which in turn forced banks to liquidate collateral. This would suggest that we focus our proposals for new regulation on the banks, the providers of collateral, rather than on the depositors. Indeed, we want to provide a safe, deposit-like account for the bulk of repo depositors. The problem is that, as discussed above, repos have many other uses as well, including the short selling of bonds for hedging purposes and the conducting of arbitrage to keep derivative prices in line with prices on the underlying assets. So any regulation of repos must make them safe for depositors while at the same time allowing for these other uses. This is the basis for our repo proposal, which distinguishes the treatment of banks from that of other entities that can use repos:

-Banks (NFBs, NSBs, and commercial banks) would be allowed to engage in repo financing, that is, the activity of borrowing money, paying interest, and providing collateral.

-Nonbank entities would also be allowed to engage in repos, but only with a license, and would face other constraints as discussed below.

-Eligible collateral for banks in repo transactions would be restricted to U.S. Treasury securities, liabilities of NFBs, and such other asset classes as the regulator deems appropriate.

-Eligible collateral for nonbank entities could be any type of security, but the transaction would be subject to minimum haircuts and position limits as specified below.

-Minimum haircuts would be required on all collateral used in repos and could be specific to the two parties and the collateral offered.

-Position limits would be set for nonbank entities, in terms of gross notional amounts issued or held, as a function of firm size and the collateral used.

—Rehypothecation would be limited automatically by the minimum haircuts. 
Eligible collateral for banks would be any bond that the regulators approve for their portfolios; this would include approved ABSs, government bonds, and possibly the debt of government-sponsored entities. As with the regulations on NFBs, the rules for eligible collateral would be analogous to 19th-century rules for collateral on bank notes.

Because of position limits and possibly higher minimum haircuts, repos outside of banks would be constrained. The advantage thus conferred on being a bank would keep this type of money creation mostly within the regulated sector but would not prevent the use of repos for a broader range of purposes other than as a deposit.

NFBs would not be required to finance all, or even part, of their portfolios using repos. Indeed, we would expect that NFBs would issue some longer-term debt, for purchase by institutional investors, and use some repo financing as well, with the relative proportions determined by supply and demand.

Nonbank licensed entities allowed to engage in repos would include, for example, hedge funds, which have usually financed themselves in the repo market. In doing so they would be borrowing against securities posted as collateral; they would not act as repo depositors. On the other side of the transaction would be a bank or other entity lending against the collateral and possibly borrowing from a third entity against this same collateral.

If none of these three entities is a bank, position limits with regard to total repos outstanding (regardless of direction) on each of the three entities would constrain this type of transaction. Haircuts would depend on the identities of the parties to a repo, in a bilateral repo, and on the type of collateral. Minimum haircuts may not be binding on some transactions, but they are likely to be meaningful because of the restriction to eligible collateral. Minimum haircuts would not prevent all runs; they would, however, limit leverage and reduce rehypothecation.

In summary, our proposed rules would create two types of allowable repo. The first type, offered by commercial banks and NFBs, would capture the monetary function of repos and would be regulated in a manner analogous to the regulation of bank notes (with regard to collateral) in the 19th century and depository institutions in the 21 st (using minimum haircuts as an analogue to capital requirements). The second type could be offered by any institution with a license and would be regulated so as to be more expensive than the first. Policymakers and the judiciary could prevent a third type, totally unregulated repos, by making clear that only the first two types receive the special bankruptcy protections. The 
repo market owes much of its existence to these protections; by offering them only to regulated repos, leakage from the regulated system could be minimized.

\section{Discussion}

Repos and securitization should be regulated because they are, in effect, new forms of banking, but with the same vulnerability as other forms of bank-created money. Like previous reforms of banking, our proposals seek to preserve banking and bank-created money but eliminate bank runs. Our proposals are aimed at creating a sufficient amount of high-quality collateral that can be used safely in repo transactions. NFBs would be overseen to ensure the creation of safe collateral, and repos would mostly be restricted to banks. Our proposals are built on the idea that these activities are efficient, in part because of the safe harbor from bankruptcy, the maintenance of which is the incentive for agents to abide by the proposed rules.

As we showed in section III, the vulnerability of bank-created money to banking panics has a long history, and the history of attempts to eliminate this problem is almost as long. Collateralization has been one successful approach. Off-balance-sheet banking has become the major source of collateral and needs to be overseen. We propose that NFBs become the entities that transform ABSs into government-overseen collateral. Repos then can be backed by this high-quality collateral.

In this paper we have not provided all the details necessary for determining acceptable collateral or for setting minimum haircuts. These details would need to be worked out in conjunction with rules for bank capital, with which they would be closely intertwined. Although it is clear that setting rules for shadow banking would make new demands on regulators, these demands would be analogous to those that arise when setting rules for banks. Whether risks are retained on the balance sheet or allowed to go off the balance sheet, there is no escaping the need for regulators to evaluate these risks. We do not see any pure private sector solutions to ensure the safety of the banking system, and so the role of regulators will remain essential. If today's regulators are found not to be up to the task, they should be better trained and better paid. If instead the task is simply impossible, then either we are destined to have more crises, or we will be forced to live with a greatly constrained financial system.

Space constraints prevent us from discussing a number of important related issues, but we will close by briefly focusing on two. The first is whether our proposals would lead to a shortage of suitable collateral, as 
apparently has happened in the past. As the crisis showed, if the volume of U.S. Treasury securities outstanding is insufficient for use as collateral, the private sector will have an incentive to try to create substitutes, such as triple-A-rated bonds. The problem is that the substitutes cannot always be information-insensitive. In 2005 the idea of the U.S. Treasury providing a backstop facility, a "securities lender of last resort," was broached (see Garbade and Kambhu 2005, U.S. Treasury 2005). Our view is that such a facility might need to be available on a regular basis, but that it should be run by the Federal Reserve, which might also need to issue its own securities to be used exclusively as repo collateral. The Federal Reserve needs to focus more carefully on the provision (and measurement) of liquidity, and it is the job of the Fed to provide collateral.

A second issue concerns monetary policy generally. Because no measure presently exists of the whole of the repo market, we do not know its full size or the extent of rehypothecation. It seems that U.S. Treasury securities are extensively rehypothecated (Krishnamurthy and Vissing-Jorgensen 2010) and therefore should be viewed as money. This means that open market operations are simply exchanging one kind of money for another, rather than exchanging money for "bonds." Open market operations may need to be rethought.

A PPENDIX

\section{Glossary of Shadow Banking Terms}

Asset-backed commercial paper (ABCP): Short-term debt issued by a bankruptcy-remote special purpose vehicle, or conduit, which uses the proceeds to purchase asset-backed securities. Such vehicles are set up by a bank or other sponsor but owned and actively managed by a management company legally separate from the sponsor. See Fitch Ratings (2001).

Asset-backed security $(A B S)$ : A bond backed by the cash flows from a pool of specified assets in a special purpose vehicle rather than by the general credit of a corporation or other entity. The asset pool may contain residential mortgages, commercial mortgages, auto loans, credit card receivables, student loans, aircraft leases, royalty payments, or any of a variety of other types of asset.

Collateralized debt obligation (CDO): An instrument issued by a special purpose vehicle that buys a portfolio of fixed-income assets, financing the purchase by issuing CDOs in tranches, whose risk ranges from low 
(senior tranches, rated triple-A) through medium (mezzanine tranches, rated double-A to $\mathrm{Ba} / \mathrm{BB}$ ), to high (equity tranches, unrated).

Rehypothecation: In the repo context, the right to freely use the bonds received as collateral for other purposes.

Narrow funding bank (NFB): A proposed new type of bank that may buy only asset-backed securities and certain other high-quality assets, as approved by a regulator. The regulator sets the portfolio criteria with respect to the proportions of asset types and their ratings. NFBs would be able to issue any nondeposit liability and would have access to the discount window but could not engage in other activities. As regulated banks, NFBs would have charters, capital requirements, and regulatory examinations.

Narrow savings bank (NSB): A proposed new type of insured depository institution into which existing MMMFs seeking deposit insurance protection could be transformed. As insured entities, NSBs would have charters, capital requirements, and regulatory examinations.

Sale-and-repurchase agreement (repo): A contract in which an investor places money with a bank or other entity for a short period and receives (and takes physical possession of) collateral valued at market prices, as well as interest. The bank or other entity simultaneously agrees to repurchase the collateral at a specified price at the end of the contract. From the perspective of the bank, the transaction is a "repo," and from the perspective of the depositor, the same transaction is a "reverse repo."

Securitization: The process of financing a portfolio of loans by segregating specified cash flows from those loans and selling securities in the capital markets that are specifically linked to those flows. The firm originating the loans (the "sponsor") sets up a special purpose vehicle to which it then sells the specified cash flows, and which issues the (rated) linked securities. The sponsor continues to service the cash flows; that is, it makes sure that the cash flows are arriving and performs certain other tasks associated with traditional lending.

Special purpose vehicle (SPV): An SPV (also called a special purpose entity, SPE) is a legal entity set up for a specific, limited purpose by a sponsoring firm. An SPV can take the form of a corporation, trust, partnership, or limited liability company, but it is not an operating company in the usual sense. It has no employees or physical location and is strictly bound by a set of rules so that it can only carry out some specific purpose or circumscribed transaction, or a series of such transactions. An essential feature of an SPV is that it is "bankruptcy remote," that is, incapable of becoming legally bankrupt and unaffected by the bankruptcy of its sponsor. See Gorton and Souleles (2006). 
Tranche: From the French for "slice," a portion of a portfolio ordered by seniority and sold separately from other portions; for example, a tripleA-rated tranche is more senior than a triple-B-rated tranche of the same portfolio.

ACKNOWLEDGMENTS We thank Stefan Lewellen, Marcus Shak, and Lei Xie for research assistance; Darrell Duffie, Victoria Ivashina, Robert Merton, Stephen Partridge-Hicks, Eric Rasmusen, Nicholas Sossidis, David Scharfstein, Andrei Shleifer, Carolyn Sissoko, Jeremy Stein, Phillip Swagel, David Swensen, Daniel Tarullo, the editors, participants at the Brookings Panel conference, and seminar participants at MIT for many helpful comments and discussions; E. Philip Davis, Ingo Fender, and Brian Reid for assistance with data; and Sara Dowling for help with the figures.

Gary Gorton was a consultant to AIG Financial Products from 1996 to 2008. Andrew Metrick served in the Obama administration during the debate and passage of the Dodd-Frank legislation. In addition, he has served as a consultant for various financial institutions. 


\section{References}

Acharya, Viral, Douglas Gale, and Tanju Yorulmazer. 2009. "Rollover Risk and Market Freezes." Working paper. New York University.

Adrian, Tobias, and Hyun Song Shin. 2010. "The Changing Nature of Financial Intermediation and the Financial Crisis of 2007-09." Staff Report no. 439. Federal Reserve Bank of New York.

Bank for International Settlements. 1999. "Implications of Repo Markets for Central Banks: Report of a Working Group Established by the Committee on the Global Financial System of the Central Banks of the Group of Ten Countries." Basel.

2007. "Institutional Investors, Global Savings and Asset Allocation." Report submitted by a Working Group established by the Committee on the Global Financial System. Basel (February).

Barth, James R., R. Dan Brumbaugh, and Robert E. Litan. 1990. "The Banking Industry in Turmoil: A Report on the Condition of the U.S. Banking Industry and the Bank Insurance Fund." Report of the Subcommittee on Financial Institutions Supervision, Regulation and Insurance of the House Banking Committee. Washington: Government Printing Office. 1992. The Future of American Banking. London: Sharpe.

Berger, Allen N., Anil K Kashyap, and Joseph M. Scalise. 1995. "The Transformation of the U.S. Banking Industry: What a Long, Strange Trip It's Been.” BPEA, no. 2: 55-201.

Boyd, John H., and Mark Gertler. 1993. "U.S. Commercial Banking: Trends, Cycles, and Policy." In NBER Macroeconomics Annual 1993, edited by Olivier Blanchard and Stanley Fischer. MIT Press.

__ 1994. "Are Banks Dead? Or Are the Reports Greatly Exaggerated?" In The Declining Role of Banking? Federal Reserve Bank of Chicago.

Brennan, John J., and others. 2009. "Report of the Money Market Working Group." Washington: Investment Company Institute (March 17).

Brunnermeier, Markus K. 2009. "Deciphering the Liquidity and Credit Crunch 2007-2008." Journal of Economic Perspectives 23, no. 1: 77-100.

Brunnermeier, Markus K., and Lasse Heje Pedersen. 2009. "Market Liquidity and Funding Liquidity." Review of Financial Studies 22, no. 6: 2201-38.

Bryan, Lowell L. 1988. Breaking Up the Bank: Rethinking an Industry under Siege. Homewood, Ill.: Dow Jones-Irwin.

Calomiris, Charles. 1989. "Deposit Insurance: Lessons for the Record.” Federal Reserve Bank of Chicago Economic Perspectives (May-June): 10-30.

1990. "Is Deposit Insurance Necessary? A Historical Perspective." Journal of Economic History 50, no. 2: 283-95.

Carey, Mark, Ricardo Correa, and Jason Kotter. 2009. "Revenge of the Steamroller: $\mathrm{ABCP}$ as a Window on Risk Choices." Working paper. Washington: Board of Governors of the Federal Reserve System.

Comotto, Richard. 2010. "A White Paper on the Operation of the European Repo Market, the Role of Short-Selling, the Problem of Settlement Failures and the 
Need for Reform of the Market Infrastructure.” Zurich: International Capital Market Association, European Repo Council.

Cook, Timothy Q., and Jeremy G. Duffield. 1979. "Money Market Mutual Funds: A Reaction to Government Regulations or a Lasting Financial Innovation?" Federal Reserve Bank of Richmond Economic Review (July-August): 15-31.

Covitz, Daniel M., Nellie Liang, and Gustavo A. Suarez. 2009. "The Evolution of a Financial Crisis: Panic in the Asset-Backed Commercial Paper Market." Finance and Economics Discussion series no. 2009-36. Washington: Federal Reserve Board.

Dang, Tri Vi, Gary Gorton, and Bengt Holmström. 2010a. "Financial Crises and the Optimality of Debt for Liquidity Provision." Working paper. University of Mannheim, Yale University, and Massachusetts Institute of Technology.

_ 2010b. "Repo Haircuts." Working paper. University of Mannheim, Yale University, and Massachusetts Institute of Technology.

Davis, Andrew McFarland. 1910. The Origin of the National Banking System. National Monetary Commission, 61 Cong. 2 sess. Document no. 582. Washington: Government Printing Office.

Demsetz, Rebecca S., Marc R. Saidenberg, and Philip E. Strahan. 1996. "Banks with Something to Lose: The Disciplinary Role of Franchise Value.” Federal Reserve Bank of New York Economic Policy Review 2, no. 2: 1-14.

Dewey, Davis R. 1910. State Banking before the Civil War. Washington: Government Printing Office.

Edwards, Franklin R., and Frederic S. Mishkin. 1995. "The Decline of Traditional Banking: Implications for Financial Stability and Regulatory Policy." Federal Reserve Bank of New York Economic Policy Review 1, no. 2: 27-45.

Fegatelli, Paolo. 2010. "The Role of Collateral Requirements in the Crisis: One Tool for Two Objectives?" Working Paper 44. Banque Centrale du Luxembourg.

Fitch Ratings. 2001. "Asset-Backed Commercial Paper Explained.” Structured Finance (November 8).

Friedman, Milton, and Anna Jacobson Schwartz. 1963. A Monetary History of the United States, 1867-1960. Princeton University Press.

Galloway, Tina M., Winson B. Lee, and Dianne M. Roden. 1997. “Banks' Changing Incentives and Opportunities for Risk Taking." Journal of Banking and Finance 21, no. 4: 509-27.

Gan, Jie. 2004. "Banking Market Structure and Financial Stability: Evidence from the Texas Real Estate Crisis in the 1980s." Journal of Financial Economics 73: 567-601.

Garbade, Kenneth D. 2006. "The Evolution of Repo Contracting Conventions in the 1980s." Federal Reserve Bank of New York Economic Policy Review (May): 27-42.

Garbade, Kenneth D., and John E. Kambhu. 2005. "Why Is the U.S. Treasury Becoming a Lender of Last Resort for Treasury Securities?" Staff Report no. 223. Federal Reserve Bank of New York. 
Geanakoplos, John. 2010. "The Leverage Cycle." In NBER Macroeconomics Annual 2009, vol. 24, edited by Daron Acemoglu, Kenneth Rogoff, and Michael Woodford. University of Chicago Press.

Golembe, Carter H. 1960. "Deposit Insurance Legislation of 1933: An Examination of Its Antecedents and Its Purposes." Political Science Quarterly 75, no. 2: 181-200.

Gorton, Gary. 1985. "Clearinghouses and the Origin of Central Banking in the United States" Journal of Economic History 45: 277-83.

- 1996. "Reputation Formation in Early Bank Note Markets." Journal of Political Economy 104, no. 2: 346-97. 33-64.

1999. "Pricing Free Bank Notes." Journal of Monetary Economics 44:

2010. Slapped by the Invisible Hand: The Panic of 2007. Oxford University Press.

Gorton, Gary B., and Andrew Metrick. 2010. "Haircuts." Federal Reserve Bank of St. Louis Review 92, no. 6.

- Forthcoming. "Securitized Banking and the Run on Repo." Journal of Financial Economics.

Gorton, Gary, and Donald J. Mullineaux. 1987. "The Joint Production of Confidence: Endogenous Regulation and Nineteenth Century Commercial-Bank Clearinghouses." Journal of Money, Credit and Banking 19, no. 4: 457-68.

Gorton, Gary, and Richard Rosen. 1995. "Corporate Control, Portfolio Choice, and the Decline of Banking." Journal of Finance 50, no. 5 (December): 1377-1420.

Gorton, Gary B., and Nicholas S. Souleles. 2006. "Special Purpose Vehicles and Securitization." In The Risks of Financial Institutions, edited by René M. Stulz and Mark Carey. University of Chicago Press.

Group of Thirty. 2009. "Financial Reform: A Framework for Financial Stability." Washington. www.group30.org/pubs/recommendations.pdf.

He, Zhiguo, and Wei Xiong. 2009. "Dynamic Debt Runs.” Working paper. Princeton University.

He, Zhiguo, In Gu Khang, and Arvind Krishnamurthy. 2010. "Balance Sheet Adjustments in the 2008 Crisis." Working Paper 15919. Cambridge, Mass.: National Bureau of Economic Research.

Hördahl, Peter, and Michael R. King. 2008. "Developments in Repo Markets during the Financial Turmoil." BIS Quarterly Review (December): 37-53.

International Capital Market Association. 2010. "European Repo Market Survey: Number 18 - conducted December 2009." Zurich.

Johnson, Christian A. 1997. "Derivatives and Rehypothecation Failure: It's 3:00 p.m., Do You Know Where Your Collateral Is?" Arizona Law Review 39: 949-1001.

Keeley, Michael C. 1988. "Bank Capital Regulation in the 1980s: Effective or Ineffective?" Federal Reserve Bank of San Francisco Economic Review, no. 1 (Winter): 3-20.

. 1990. "Deposit Insurance, Risk, and Market Power in Banking." American Economic Review 80, no. 5: 1183-1200. 
Keeley, Michael C., and Gary C. Zimmerman. 1985. "Competition for Money Market Deposit Accounts.” Federal Reserve Bank of San Francisco Economic Review 2: 3-27.

Kettering, Kenneth C. 2008. "Securitization and Its Discontents: The Dynamics of Financial Product Development.” Cardozo Law Review 29, no. 4: 1553-1728.

Klee, Kenneth N., and Brendt C. Butler. 2002. "Asset-Backed Securitization, Special Purpose Vehicles and Other Securitization Issues.” Uniform Commercial Code Law Review 35, no. 2: 23-67.

Knox, John Jay. 1900. A History of Banking in the United States. New York: Bradford Rhodes \& Company.

Krimminger, Michael. 2006. "The Evolution of U.S. Insolvency Law for Financial Market Contracts.” Washington: Federal Deposit Insurance Corporation.

Krishnamurthy, Arvind. 2010. "How Debt Markets Have Malfunctioned in the Crisis." Journal of Economic Perspectives 24, no. 1: 3-28.

Krishnamurthy, Arvind, and Annette Vissing-Jorgensen. 2010. "The Aggregate Demand for Treasury Debt." Working paper. Kellogg School, Northwestern University.

Liu, Henry C. K. 2003. "The Global Economy in Transition.” Invited lecture at the ERC/METU International Conference on Economics, Ankara, Turkey, September 6. www.henryckliu.com/page181.html.

Marcus, Alan. 1984. "Deregulation and Bank Financial Policy.” Journal of Banking and Finance 8: 557-65.

Martin, Antoine, David Skeie, and Ernst-Ludwig von Thadden. 2010. "Repo Runs." Staff Report no. 444. Federal Reserve Bank of New York.

Moody's Investors Service. 1997a. "Alternative Financial Ratios for the Effects of Securitization." (Reprinted in Securitization and Its Effect on the Credit Strength of Companies: Moody's Perspective 1987-2002, Special Comments. New York: Moody's, 2002).

1997b. "The Costs and Benefits of Supporting 'Troubled' Asset-Backed Securities: Has the Balance Shifted?" (Reprinted in Securitization and Its Effect on the Credit Strength of Companies: Moody's Perspective 1987-2002, Special Comments. New York: Moody's, 2002).

Morgan, Donald P. 2002. "Rating Banks: Risk and Uncertainty in an Opaque Industry.” American Economic Review 92, no. 4: 874-88.

Pagano, Marco, and Paolo Volpin. 2008. "Securitization, Transparency, and Liquidity.” Working paper. Universitá di Napoli Federico II and London Business School.

Plank, Thomas E. 2007. "Toward a More Efficient Bankruptcy Law: Mortgage Financing under the 2005 Bankruptcy Amendments." Southern Illinois University Law Review 31, no. 3: 641-68.

Rockoff, Hugh. 1974. "The Free Banking Era: A Reexamination.” Journal of Money, Credit and Banking 6, no. 2: 141-67. 
Rolnick, Arthur, and Warren Weber. 1984. "The Causes of Free Bank Failures: A Detailed Examination." Journal of Monetary Economics 21: 47-71.

Schroeder, Jeanne L. 1996. "Repo Madness: The Characterization of Repurchase Agreements under the Bankruptcy Code and the U.C.C." Syracuse Law Review 46: 999-1050.

Schwarcz, Steven L. 2002. "Impact of Bankruptcy Reform on 'True Sale' Determination in Securitization Transactions." Fordham Journal of Corporate and Financial Law 7: 353-64.

Schweitzer, Lisa, Seth Grosshandler, and William Gao. 2008. "Bankruptcy Court Rules That Repurchase Agreements Involving Mortgage Loans Are Safe Harbored under the Bankruptcy Code, but That Servicing Rights Are Not." Journal of Bankruptcy Law (May-June): 357-60.

Shleifer, Andrei, and Robert W. Vishny. 2009. "Unstable Banking." Working Paper no. 14943. Cambridge, Mass.: National Bureau of Economic Research.

Singh, Manmohan, and James Aitken. 2010. "The (Sizable) Role of Rehypothecation in the Shadow Banking System.” IMF Working Paper WP/10/172. Washington: International Monetary Fund.

Sissoko, Carolyn. 2010. "The Legal Foundations of Financial Collapse.” Journal of Financial Economic Policy 2, no. 1: 5-34.

Smith, Edwin E. 2008. "Financial Contracts under the Bankruptcy Code." ABI Committee News 5, no. 2 (May): 536-41.

Stark, Robert. 2002. "Viewing the LTV Steel ABS Opinion in Its Proper Context." Journal of Corporation Law 27: 211-30.

Uhlig, Harald. 2009. “A Model of a Systemic Bank Run.” Journal of Monetary Economics 57, no. 1: 78-96.

U.S. Treasury. 2005. “TBAC Discussion Charts, November 1, 2005.” Washington. www.treas.gov/offices/domestic-finance/debt-management/adv-com/minutes/ dc-2005-q4.pdf.

U.S. Treasury, Securities and Exchange Commission, and Board of Governors of the Federal Reserve System. 1992. The Joint Report on the Government Securities Market. Washington. www.ustreas.gov/offices/domestic-finance/debtmanagement/gsr92rpt.pdf.

Walters, Gary. 1984. "Repurchase Agreements and the Bankruptcy Code: The Need for Legislative Action." Fordham Law Review 52: 828-49. 


\section{Comments and Discussion}

\section{COMMENT BY}

ANDREI SHLEIFER This fascinating paper by Gary Gorton and Andrew Metrick provides an extremely useful overview of the shadow banking system, puts it into historical perspective, explains how it is responsible for the financial crisis, and makes a proposal for how to fix it. Yet the paper is much more than an overview, and in some crucial ways it provides a highly distinctive perspective. This perspective consists of four propositions.

First, starting with the widely accepted notion that the defining feature of the shadow banking system is securitization, the paper goes on to argue that the essential aspect, indeed the raison d'être, of securitization is maturity transformation, that is, the transformation of long-term financial instruments, such as mortgages, into short-term securities, such as repos and commercial paper. Securitization became so massive, in the authors' view, not so much to create allegedly safe long-term securities through diversification and the tranching of risky debt, as many economists have argued, but rather to use these securities to provide fodder for short-term finance. Long-term securities, in this view, served mainly as collateral for short-term borrowing instruments. It is the demand for short-term securities from money market mutual funds and other short-term investors that made securitization possible.

Second, the paper argues that the abrupt withdrawal of short-term finance was responsible for the financial crisis. Because investors in shortterm securities expected complete safety, the realization that these securities might be at risk caused them to withdraw financing on very short notice. This withdrawal took the form of rapidly rising haircuts on repo transactions or even runs. When the dealer banks that engineered the maturity transformation faced this withdrawal of short-term finance, they had to 
liquidate the positions they had financed with short-term debt, triggering massive losses, declines in their balance sheets, and reductions in their ability to finance either their existing holdings or other investments.

Third, among the several different forms of short-term finance associated with the maturity transformation, the real culprit for the increase in financial fragility, in the authors' view, is the repo. Repo financing of asset-backed securities (ABS) holdings was particularly aggressive because by law repos are bankruptcy remote: the parties extending such collateralized finance do not become part of the bankruptcy estate should the borrower default. Such regulatory protection of repo finance, Gorton and Metrick maintain, caused it to grow to gigantic levels. Its withdrawal, or the sharp increase in its cost, is therefore primarily responsible for the crisis.

Fourth, in the light of the above three points, the paper argues that the route to financial stability is to regulate repo financing of ABS holdings. This would be done by, first, forcing all ABSs to be rated by a governmentregulated agency and sold to specialized narrow banks; second, restricting the quantity of ABSs that can be financed with repos and the terms of that financing; and third, more closely regulating the lenders in the repo market, particularly the money market mutual funds.

As I explain below, all four of these distinctive propositions are, to varying degrees, controversial. I am not suggesting that I know that they are wrong. Rather, my goal is to point out that information is extremely limited even today about exactly who were the various buyers of ABSs, what was the extent of maturity transformation, and even what were the main sources of financial fragility. We do know by now that the Federal Reserve did not collect the information that would today, 2 years later-let alone in 2008-enable us to answer these questions with confidence. We also know that neither the Federal Reserve nor many of the major market participants, such as AIG and Citibank, understood the vulnerability of shadow banking at the time of the crisis. What really happened is still largely a matter of guesswork. It may well turn out that Gorton and Metrick's assessments are correct, and then in retrospect they will look like geniuses, but my intention is to identify the areas of extreme uncertainty in our knowledge today.

To begin, the fundamental assumption of the Gorton and Metrick narrative is that securitization was, to a first approximation, all about providing fodder for short-term riskless finance. For this to be the case, it must be that nearly all ABSs, or at least the lion's share, were financed short-term by their holders. It is surely the case that a good deal of ABSs went into 
structured investment vehicles (SIVs) or were held by dealer banks themselves, and in these instances, short-term finance was common. Yet at least some, and possibly a good part, of ABSs were acquired by pension funds, insurance companies, and even government-sponsored enterprises. For those buyers, short-term financing was probably much less important. The reason this observation is of some consequence is that Gorton and Metrick's regulatory proposal would require that all ABSs be maturity transformed, which presumably would prevent their being sold to investors in long-term securities. I am far from certain that this would be desirable.

Gorton and Metrick's second assumption is that the withdrawal of this short-term finance was responsible for the crisis. This assumption seems plausible, since sharp reductions in short-term financing did occur around the time of Lehman Brothers' failure, but even here there are some issues. First, the reductions in short-term financing of long-term positions in ABSs began in the summer of 2007, as the market for asset-based commercial paper dried up. This withdrawal of short-term financing was countered by several liquidity interventions from the Federal Reserve, which successfully delayed the collapse of the markets until the fall of 2008.

Second, and more important, it is far from clear whether the withdrawal of short-term financing in August and September 2008 actually precipitated the collapse or was, alternatively, its consequence. After all, bad news about both housing and commercial real estate was coming into the market throughout 2008, making it increasingly clear that several of the major financial institutions were insolvent. Was the withdrawal of short-term finance a response to this realization of insolvency, or did it actually precipitate the insolvency? Following Douglas Diamond and Philip Dybvig (1983), economists often use the term "run" to describe a multiple-equilibrium situation, in which a bad equilibrium with a run can occur despite solid fundamentals. Such a run does not seem to be a good description of what happened to Lehman and other banks in 2008. The withdrawal of short-term finance surely undermined bank balance sheets, but it seems to me at least as plausible that this withdrawal was a response to an already incurable situation rather than its cause. And if that is the case, regulating short-term finance might not be as high a priority as Gorton and Metrick indicate.

Gorton and Metrick's third assumption, namely, that repo financing of ABSs was the source of instability in the financial system, is the most controversial. Dealer banks relied on a variety of short-term financing mechanisms, including not only repo but also prime brokerage and commercial paper. Prime brokerage enabled dealer banks to use the assets they held on 
Figure 1. Overnight Repos and Commercial Paper of Financial Institutions Outstanding, 1994-2009

July 4, $1994=1.0$

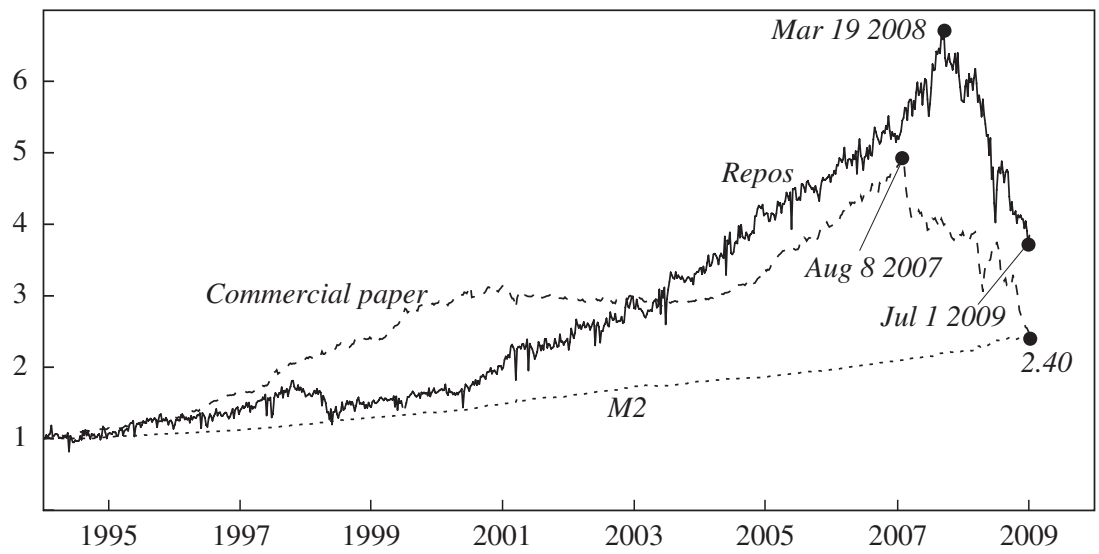

Source: Adrian and Shin (2010).

behalf of their brokerage clients as collateral for their own borrowing. The withdrawal of those accounts was apparently extremely costly to Bear Stearns and perhaps other dealer banks. Commercial paper is, of course, the most traditional form of short-term financing and was hugely important in the years before the crisis. Indeed, the SIVs, which were the institutions most centrally involved in the maturity transformation, financed themselves with commercial paper, and not with repos. My figure 1, taken from Tobias Adrian and Hyun Song Shin (2010), shows outstanding volumes of repos and commercial paper around the time of the crisis. The two series show extremely similar patterns of extraordinary growth before the crisis, followed by a rapid collapse. How do Gorton and Metrick know that, even assuming that the withdrawal of short-term finance in August and September 2008 was at the heart of the crisis, it was repos rather than commercial paper that tipped the balance? Lehman, after all, defaulted on its commercial paper. This issue is critical since commercial paper is not an innovation but a very old financial instrument (the Federal Reserve's 1913 charter gives it responsibility for that market), and in particular it does not enjoy the legal advantages with respect to bankruptcy that repos do. It would seem a bit audacious to lay the blame on repos' bankruptcy remoteness when commercial paper financing follows a nearly identical pattern of growth and decline. 
There are some further reasons to doubt that repos were the straw that broke the camel's back. Most fixed-income repo financing uses government or agency bonds as collateral. ABSs are used as collateral in only a relatively small share of the repo market, and it seems highly doubtful to me that repo financing of their own ABS holdings was important for dealer banks. There is no evidence that the repo market in government or agency paper malfunctioned badly during the crisis. Moreover, many dealer banks are just intermediaries in repo financing: they borrow securities from hedge funds and provide them with short-term financing, and then lend these securities on to cash-rich, often foreign, banks and borrow cash from them. So long as the dealer banks can count on getting the hedge funds to cough up additional cash when the haircuts on loans rise, the situation is stable. To elevate ABS repos to the prominence in the crisis that Gorton and Metrick wish to assign to it, they need to provide a good deal more evidence.

These reservations bring me to their policy proposal, which of course would require a major regulatory overhaul of the whole shadow banking system. Let me not focus on the question of whether, if the underlying assumptions of the Gorton and Metrick analysis are correct, their proposal would be a good idea. I understand that the Federal Reserve Bank of New York considered a similar proposal a while ago and decided against it because it was impractical. Let me instead come back to the three assumptions.

First, if implemented, the proposal to allow only narrow funding banks to purchase ABSs would deprive buyers of ABSs not interested in shortterm instruments of access to these securities. If, as the authors believe, securitization reduces the cost of capital for desirable investment projects, and if much of the demand comes from investors uninterested in shortterm finance of their positions, shutting off this demand might not promote efficiency.

Second, if short-term finance was not the culprit during this crisis, but instead the problem was, for example, the failure of financial intermediaries to understand the risks of the securities they were holding, it is not clear how the proposal addresses the central problem. Would the world be a safer place if dealer banks maintained large holdings of ABSs, or provided guarantees to SIVs, without relying on short-term finance? Presumably, when these institutions are subject to capital requirements and other regulations, they still face huge pressure to shrink their balance sheets when they suffer losses.

Third, and perhaps most important, if ABS repos do occupy the central position in the crisis to which Gorton and Metrick have elevated them, 
then the singular focus on this market might leave the system as a whole just as fragile as it was before. If the government raises the cost of one form of short-term financing and does nothing else, presumably the dealer banks will turn to other forms. I agree wholeheartedly with Gorton and Metrick that the existing financial infrastructure failed miserably during the crisis, but I would wish to have a bit more confidence that we are wrecking and replacing the parts of it that are actually rotten rather than the ones that are not.

In this regard, let me make one final point, to which I have already alluded. It seems to me that the fundamental cause of the financial crisis is that market participants, as well as the regulators, did not understand the risks inherent in ABSs and other new types of securities. They did not expect that home prices could fall so much and so fast and in so many places at once. They did not understand correlations in home prices and defaults. They used incorrect models. It is not just the ratings agencies that messed things up, but the whole market misunderstood the risks, as is clear from the fact that the price of risk was extremely low in the summer of 2007 and did not rise much in the months after that.

As long as market participants do not understand the risks of the securities they are buying, whether these securities are ABSs or prime money market fund shares or something that will be invented in the future, and see profit opportunities in places where there are none, the financial system will adjust to meet their demand (see Gennaioli, Shleifer, and Vishny 2010). One implication of this is the standard point that providing the intermediaries with bigger cushions of capital and liquidity is desirable. But perhaps a deeper point is that in such environments where important risks are misunderstood, shutting down one mechanism whereby investors and intermediaries pursue their profits is unlikely to work. They will try to realize their dreams through other instruments instead. Regulating a particular instrument, or a particular segment of the market, to solve a more fundamental problem is highly unlikely to work.

\section{REFERENCES FOR THE SHLEIFER COMMENT}

Adrian, Tobias, and Hyun Song Shin. 2010. "The Changing Nature of Financial Intermediation and the Financial Crisis of 2007-2009." Annual Review of Economics 2: 603-18.

Diamond, Douglas W., and Philip H. Dybvig. 1983. "Bank Runs, Deposit Insurance, and Liquidity." Journal of Political Economy 91, no. 3: 401-19.

Gennaioli, Nicola, Andrei Shleifer, and Robert W. Vishny. Forthcoming. "Neglected Risks, Financial Innovation, and Financial Fragility." Journal of Financial Economics. 


\section{COMMENT BY}

DANIEL K. TARULLO Broadly speaking, threats to financial stability can arise in two ways: first, through the rapid deterioration or failure of a large institution with leverage sufficient to have widespread knock-on effects, and second, through the breakdown of a significant market in which large numbers of leveraged actors depend upon similar sources of liquidity and, importantly, backup liquidity in periods of stress. These two sources of systemic risk can be, and usually are, related. In fact, the severity of the recent crisis might be explained as an explosive combination of the two. But the different origins of risk call for different or, perhaps more precisely, complementary, policy responses. ${ }^{1}$

To date, reform in financial regulation and supervision has focused mainly on large regulated institutions. Three examples are the justannounced Basel III capital rules, much of the Dodd-Frank Act, and the Federal Reserve's revamping of its supervision of large holding companies. Of course, attention has also been paid to the second source of systemic risk, notably in Dodd-Frank's provisions for prudential supervision of payments, clearing, and settlement systems. But more will need to be done in this area, particularly as new constraints applicable to large regulated institutions push more activity into the unregulated sector.

This paper by Gary Gorton and Andrew Metrick fits squarely within this enterprise. It builds on two important insights from work that Gorton was pursuing well before the financial crisis began. The first was that the enormous growth of the shadow banking system generally, and the repurchase agreement, or "repo," market specifically, depended on the engineering of triple-A-rated securities that led participants to believe they did not need to inquire into the soundness of the underlying collateral. This financial engineering largely succeeded in insulating participants from idiosyncratic risk. But when the value of whole classes of the underlying collateral was drawn into serious question, initially by the collapse of the subprime housing market, participants' lack of information about the collateral they held led to a shattering of confidence in all the collateral.

In the absence of the regulation and government backstop that have applied to the traditional banking system since the Depression, a run on assets in the entire repo market ensued. The resulting forced sale of assets into an illiquid market turned many illiquid institutions into insolvent ones.

1. The views presented here are my own and not necessarily those of other members of the Board of Governors of the Federal Reserve System or the Federal Open Market Committee. Tom King and Michael Palumbo of the Board staff contributed to these remarks. 
The fallout has been such that, to this day, the amount of repo funding available for nonagency residential mortgage-backed securities, commercial mortgage-backed securities, high-yield corporate bonds, and other instruments backed by assets with any degree of risk remains substantially below its pre-September 2008 levels.

The second insight of Gorton's on which this paper builds is the importance of statutory franchise value for the business model viability of at least some kinds of regulated financial entities. Where competition from unregulated entities is permitted, whether explicitly or de facto, capital and other requirements imposed on regulated firms may shrink margins enough to make them unattractive to investors. The result, as in the past, will be some combination of regulatory arbitrage, assumption of higher risk in permitted activities, and exit from the industry. Each of these outcomes at least potentially undermines the original motivation for the regulation.

Gorton and Metrick provide a concrete, although rather skeletal, proposal to remedy the information problem in the repo market through creation of statutory franchise value for what they call narrow funding banks (NFBs). These banks would be "narrow" in that their only assets would be asset-backed securities (ABSs) and very high quality instruments such as Treasury securities. They would, it appears, make their money from the income streams associated with the ABSs. They would raise the funds to purchase ABSs through debt issuance and, most significantly for the proposal, the repo market, in which the collateral offered would be liabilities of the NFBs. The government would regulate the NFBs directly, as it does all banks, but also by setting requirements for the ABSs that could be bought by the NFBs. This regulation is intended to provide market confidence in the liabilities of the NFBs, which would be further buttressed by NFB access to the discount window.

A key feature of the proposal is that, by law, only NFBs could buy securitized assets. The consequent franchise value would compensate NFBs for the costs they incur because they can hold only high-quality securities, are subject to supervision and prudential requirements, and have to operate in a highly transparent fashion. In essence, ABS-backed repo funding would be limited to NFBs.

The first two questions I would pose about this creative policy proposal are the most basic: What problem is it supposed to solve, and how does the breadth of the remedy align with that problem? Given their analysis of the breakdown of the repo market, Gorton and Metrick's answer might be self-evident: Their proposal aims to solve the information problems that increased the risk from maturity transformation associated with ABS repo 
funding. This, of course, is not a solution for the entire shadow banking system, although an effective plan for reforming the ABS repo market would be a major accomplishment in itself. ${ }^{2}$

But the solution that Gorton and Metrick propose to this problem would significantly restrict all asset-backed securitization. Although it is obvious that too much credit was created through ABSs and associated instruments in the years preceding the crisis, it seems at least reasonable to question whether the best policy response is this dramatic a change in the regulatory environment. One wonders, for example, if it is desirable to forbid anyone but NFBs from buying ABSs, particularly if there are investors interested in holding these assets regardless of their utility in repo arrangements. The severe problems now associated with ABSs began with assets held by mismatched entities like structured investment vehicles or financial institutions engaged in capital arbitrage under Basel II, not those held by end investors.

A variant on this initial question is how much the legal environment for securitization should be changed in order to provide a source of stable short-term liquidity in wholesale funding markets. Limiting securitization purchases to NFBs would surely result in some tailoring of ABSs to the business models of NFBs, an outcome that might not be identical to a securitization market tailored to the funding needs of lenders providing credit to businesses and consumers. Also, as I will explain later, Gorton and Metrick's proposal would require nontrivial changes in bank regulatory policy, as well as the significant extension of discount window access to a new kind of institution. All this would be in pursuit of a mechanism for generating large amounts of liquidity. A cost-benefit discussion is probably needed at the outset, with careful specification of the benefits of the repo market that the authors are trying to save, weighed against the likely impact on, among other things, the securitization market and the regulatory system.

A second set of questions concerns how the NFBs would operate in practice. As a threshold matter, it is worth noting that policymakers may find the proposal to have a certain binary quality. That is, it would structurally change the entire securitization market and a large portion of the repo market essentially overnight. In effect, Gorton and Metrick put all securitization eggs into one basket. If the new system worked well, the benefits presumably would be significant, and perhaps quickly realized. Indeed, the new system might succeed in helping to restart, on a sounder basis, various ABS submarkets that remain largely dormant 3 years after

2. For a survey of the entire shadow banking system, see Pozsar and others (2010). 
the crisis began to unfold. ${ }^{3}$ If, on the other hand, the new system encountered major difficulties, there might be materially reduced adaptive capacity in other financial actors, possibly for a considerable period.

One obvious source of difficulty is the possibility, well recognized by Gorton and Metrick, that the business model mandated for NFBs might not be viable and stable. Like all forms of narrow banks proposed over the years, NFBs as a group would seem likely to generate relatively low revenue, given the low risk of the securities in which they would have to invest. Gorton and Metrick propose to counter this problem by granting franchise value through the statutory monopoly on securitization mentioned earlier and through access to the Federal Reserve's discount window. Picking up on their analogy to the creation of deposit insurance in the 1930s, the monopoly on securitization is intended to help offset the regulatory costs imposed on NFBs in the same way that the monopoly on the "business of banking" was intended to offset the regulatory costs imposed on insured depository institutions.

Unlike the business environment for banks in the 1930s, however, securitization and repo lending are national, if not international, activities, with little to suggest that any advantage would be derived from local knowledge. It seems quite possible that the economies of scale associated with the NFB model are sufficiently high that the industry structure would tend toward oligopoly, or even monopoly. That is, too much franchise value might be created. In that event there would be significant additions to the cost side of the proposal's ledger, in the form of the price and quantity effects that result from noncompetitive industry structures.

Regardless of the eventual structure of the industry, NFBs essentially would be monolines, with highly correlated risk exposures. They could be particularly vulnerable to funding difficulties in times of deteriorating credit conditions. Yet by the terms of Gorton and Metrick's proposal, they apparently would not be able to hedge interest rate or other risks. The authors propose giving NFBs access to the discount window to forestall liquidity problems and runs on the NFBs, presumably in the same way that deposit insurance stopped runs on traditional banks. Here again, though, the analogy is not a perfect one. Whereas banks and their depositors are assured that the Federal Deposit Insurance Corporation will keep the latter

3. The relative dormancy of these markets is also due in part to the limited supply of the loans needed to feed the securitization process. 
whole in the event of the former's failure, the Federal Reserve does not make binding commitments to lend to any institution and actively discourages reliance on the window for regular funding. In this regard, it is noteworthy that the haircuts imposed on collateral presented at the discount window rose during the recent crisis, although to a lesser extent than in the repo market itself.

A third question about the Gorton and Metrick proposal arises because of the significant changes in current law and practice that it would require. The prohibition on ABS holdings by anyone other than NFBs is the obvious and major example. But there are several others. In addition to the possibly problematic features of discount window lending in general for the proposal, the Federal Reserve has traditionally opened the window to nondepository institutions only in particularly stressed conditions. Under the Dodd-Frank Act, any use of credit ratings in federal regulations will be prohibited, an obvious complication to the proposal. This part of DoddFrank has accelerated and expanded the efforts already under way at the federal banking agencies to lessen regulatory reliance on ratings. In truth, it may pose no greater challenge for this proposal than for many existing capital rules. ${ }^{4}$ Still, it may require extension of the authors' confidence that the regulator could adequately oversee ABS ratings to confidence that it could assign ratings in the first place. I would observe that the substantial effort expended by staff at the Board and at the Federal Reserve Bank of New York to evaluate the creditworthiness of a relatively small number of securitizations in the Term Asset-Backed Securities Loan Facility (TALF) suggests the enormity of that task. Furthermore, the wisdom of having a government agency-even the independent central bank-assume such a permanent, central role in credit allocation is at least subject to debate.

A final regulatory issue is raised by another feature of Gorton and Metrick's proposal prompted by their expectation that equity returns for NFBs will be lower than for traditional banks. In place of the equity capital requirements generally applicable to banking organizations, they propose that NFBs issue capital notes that would be debt-like except in periods of stress, when they would convert to equity. In essence, all of an NFB's capital would be contingent capital. Although contingent capital is an item on the financial regulatory agenda, it is considered a possible supplement to

4. For a discussion of some of the issues raised in the context of capital requirements, see Board of Governors of the Federal Reserve System (2010). 
common equity, not a substitute for it. In this respect, the proposal moves in the opposite direction from Basel III, which has followed markets in making common equity the centerpiece of capital evaluation and requirements. ${ }^{5}$

These inconsistencies with current law and practice in the Gorton and Metrick proposal do not themselves argue against its soundness. They do, however, underscore the degree to which the NFBs would require development of a new financial regulatory approach, as well as a restructuring of the ABS and repo markets.

More generally, the existence of costs or problems with the proposal is not sufficient grounds to reject it. In the face of very real flaws in the precrisis state of these markets, and the failure of some ABS markets to recover, even where it seems they could function sensibly, there is a very good case for such a policy initiative. So let me consider briefly whether variants on Gorton and Metrick's basic approach might retain its core benefits while addressing some of its potential problems.

One possibility would be to broaden the permissible ownership of NFBs to include bank holding companies. This modification would make the most sense if one believed that the proposal's basic approach was promising but that the risks of either an untenable business model or high industry concentration, and consequent anticompetitive effects, were high. It is possible that a number of large, diversified financial holding companies would find an NFB a viable part of their operations. Gorton and Metrick would require, however, that NFBs be stand-alone entities, and they would specifically prohibit ownership by commercial banks, in an effort to avoid implicit contractual guarantees. This is a legitimate concern, to be sure, but one that might be at least imperfectly addressed through specific restrictions on relationships between affiliates in a bank holding company. The relevant comparison is thus between the residual costs of the regulated relationship and the effects of an anticompetitive industry structure.

A second variant, also motivated by industry structure problems, would be to turn NFBs from what in Gorton and Metrick's proposal are essentially privately owned public utilities into actual public utilities. However, the extent to which this change in ownership structure would ameliorate the anticompetitive problems is uncertain. Moreover, the concerns mentioned earlier with respect to government judgments on credit allocation

5. It also seems likely that the kinds of quantitative liquidity requirements currently under development by the Basel Committee on Banking Supervision would be difficult for NFBs to satisfy. 
would remain, even if they are provided another layer of insulation through the device of a government corporation. In addition, of course, the history of Fannie Mae and Freddie Mac is a cautionary tale of the potential for a government monopoly with a conservative mandate to expand its operation into much riskier activities.

At first glance, then, it is not at all clear that structural modifications to Gorton and Metrick's basic approach would be preferable to the proposal as they have described it. Options that depart from their approach would need to find different ways of solving the information problems that they identify. Let me briefly note some possible alternatives that would use regulatory requirements to create a class of $\mathrm{ABSs}$ in which markets could, without inquiry into the nature and quality of the underlying assets, have confidence even in periods of stress. One way, of course, would be to follow more closely the deposit insurance analogy by establishing an insurance system, a proposal that Gorton and Metrick endorse with respect to money market funds. They suggest, however, that an insurance system for securitization markets would be impractical because of the existence of multiple tranches, at least some of which would be uninsurable and thus would, in their view, exacerbate rather than ameliorate information problems.

Another alternative would begin with an important idea that the paper mentions, but which is not at the center of the proposal: making the repo bankruptcy exception available only where the collateral conforms to certain criteria established by law or regulation. Given the demand for repo funding, it seems worth considering whether this device could be used to create the franchise value necessary to sustain a sizable wholesale funding market subject to safety and soundness regulation. Indeed, if this approach has promise, it might be feasible for a regulatory body to establish the requisite criteria without providing insurance. With or without insurance, the "franchise value" might attach more to the instrument than to an institution.

It is beyond the scope of this comment to enumerate the potential difficulties with these ideas, but they are not hard to discern. In common with the authors' proposal, they would require a level of expertise and involvement in credit rating by the government that could pose practical and, in some conceivable versions, policy concerns. In any case, these are thoughts for further discussion, rather than developed options. Gorton and Metrick have, in setting forth this proposal, continued to shape our understanding of the role and risks of the shadow banking system, while adding a specific proposal to our menu of possible responses. 


\section{REFERENCES FOR THE TARULLO COMMENT}

Board of Governors of the Federal Reserve System. 2010. "Advance Notice of Proposed Rulemaking Regarding Alternatives to the Use of Credit Ratings in the Risk-Based Capital Guidelines of the Federal Banking Agencies." Joint Advance Notice of Proposed Rulemaking. Washington (August 10). www.federal reserve.gov/newsevents/press/bcreg/bcreg20100810a1.pdf.

Pozsar, Zoltan, Tobias Adrian, Adam Ashcraft, and Hayley Boesky. 2010. "Shadow Banking." Federal Reserve Bank of New York Staff Reports no. 458 (July). www.newyorkfed.org/research/staff_reports/sr458.pdf.

GENERAL DISCUSSION Jonathan Parker noted that runs on highly rated securities had also happened in money market mutual funds. Under current regulation, the quality of a money market fund cannot easily be discerned, and the structure of the fund gives fund managers little incentive to become informed about the quality of highly rated assets. Thus, there is often a trade-off between higher returns and an unknown amount of additional risk. Given the short-term nature of these investments, there is not only little incentive to gather information, but often little time to gather it when it becomes clear that information is needed. There is thus a trade-off in regulation between liquidity - the speed with which money can be withdrawn (or not rolled over) — and information creation. If something goes wrong and the asset is withdrawable on demand or in the short term, I can get out, but I will not be able to process whether that was the right decision. The solution then seems to be to increase the terms of lending to promote stability, so information can be gathered, but this comes at the cost of liquidity. Parker also noted, with respect to the securitization model, that there is no reason originators cannot be required to sell systemic securitized risk to be insured against a macro crisis, while at the same time holding the idiosyncratic risk of their loans for incentive reasons.

Robert Hall observed that the financial world has a thirst to hold wealth with a zero probability of negative nominal return. The issue raised by the paper is the value of creating institutions that cannot go bankrupt. In a low-inflation economy, this issue of preventing negative nominal returns is an important one, suggesting a simple change: rather than raise inflation, depositors should get a lower return in exchange for a lower probability of a negative return, while still allowing for the possibility.

Kristin Forbes suggested that the paper was in effect saying that the shadow banking system arose to compensate for shortcomings in the bankruptcy system, and especially the length of time to resolve a bankruptcy case. If that is so, one would expect that countries with stronger bankruptcy 
regimes and faster bankruptcy resolution would have smaller shadow banking systems. Do the cross-country data support this? Her prior was that they did not. Countries such as the United States have fairly strong and effective bankruptcy systems yet have the largest shadow banking systems.

Phillip Swagel thought that Andrei Shleifer's concern over the authors' proposal involving nationalization of the nonagency repo market was misplaced. The proposal would remove some of the existing legal protection for repo transactions that do not involve high-quality collateral. Thus, it would reduce government coverage, not increase it. This seemed to Swagel a reasonable way to provide an incentive for the use of better collateral. On the other hand, there should be greater understanding of the limits to which high-quality collateral matters. The week after Lehman Brothers failed, the U.S. Treasury offered insurance for money market mutual funds. What was striking was that essentially all of these funds-even those that invested only in securities that were already government-guaranteed, such as Treasury and agency bonds - chose to buy the insurance. These funds already had the highest-quality collateral, yet it didn't matter; they wanted to provide even more reassurance to investors. The lesson Swagel drew was that in a true crisis, even the best collateral is not good enough.

Steven Davis argued that it was not obvious how the authors' proposal flowed from their interpretation of the crisis. Excessive leverage was what contributed in many ways to the crisis, facilitating the housing bubble, among other things. Thus, the regulatory system needs to be able to regulate leverage, for example through haircuts. For Davis, this implied a different solution: that banks be required to hold more capital, since the world is riskier than previously thought.

Ricardo Reis was interested in the idea of repos as a way around bankruptcy. He raised three issues. First, in the cross section of countries, do we see more use of repos (or similar instruments) in countries with the least efficient bankruptcy procedures? Second, across industries, are repos used more in industries where finances are more opaque? And third, if the problem was the delays caused by bankruptcy proceedings, why not reform the bankruptcy code? 